\title{
Explicit Consent-By-Registration: Plaintiffs' New Hope After the "At Home" Trilogy
}

\author{
Chris Carey*
}

\section{INTRODUCTION}

The United States Supreme Court recently added another decision to what is now a trilogy of cases that together upend decades of settled personal jurisdiction precedent. ${ }^{1}$ With its opinions in Goodyear, Daimler, and Tyrrell, the Court expressed renewed interest in an issue ordinarily receiving little space on the Court's crowded docket: general personal jurisdiction. ${ }^{2}$ The trilogy cases replace the Court's traditional "minimum contacts" analysis for general jurisdiction with an "at home" rule. ${ }^{3}$ The at home rule states that, absent exceptional circumstances, courts may only subject corporations to general jurisdiction in their state of incorporation and principal place of business. ${ }^{4}$ The at home rule significantly narrows the scope of general jurisdiction, arming corporate defendants with a new weapon in their pre-trial arsenals and sending the plaintiffs' bar in search of alternative jurisdictional theories. ${ }^{5}$ One such

* J.D. Candidate, 2019, University of Kansas School of Law; B.A. Political Science, University of Kansas, 2016. I would like to thank Professor Ellen Sward for her invaluable insight and revisions of this Comment. I would also like to thank Ashely Billam, Nancy Musick, Paul Keithley, and the rest of the Kansas Law Review staff for their rigorous edits and suggestions.

1. See, e.g., Ryan N. Parsons, BNSF Railway: SCOTUS Narrows General Jurisdiction for Corporate Defendants and Limits the Reach of Wisconsin's Long-Arm Statute, WiS. APP. L. (June 5, 2017), https://www.wiappellatelaw.com/2017/06/05/bnsf-railway-scotus-narrows-general-jurisdict ion-for-corporate-defendants-and-limits-the-reach-of-wisconsins-long-arm-statute/ [https://perma.cc /932U-UDAK] (discussing the three recent general jurisdiction cases as having "redefined the limits of constitutional due process").

2. Goodyear Dunlop Tires Operations, S.A. v. Brown, 564 U.S. 915 (2011); Daimler AG v. Bauman, 571 U.S. 117 (2014); BNSF Ry. Co. v. Tyrrell, 137 S. Ct. 1549 (2017). Before 2011, the Court had only decided two general jurisdiction cases, Perkins v. Benguet Consolidated Mining Co., 342 U.S. 437 (1952) and Helicopteros Nacionales de Colombia, S.A., v. Hall, 466 U.S. 408 (1984). See Jack B. Harrison, Registration, Fairness, and General Jurisdiction, 95 NEB. L. REV. 477, 49095 (2016) (discussing the Court's two general jurisdiction cases after International Shoe).

3. See Harrison, supra note 2, at 507 ("[Goodyear and Daimler] radically transformed the traditional understanding of general jurisdiction.... [and] injected a far more categorical and restrictive approach ... than seen in any of its prior jurisprudence.").

4. Daimler, 571 U.S. at 137.

5. See Harrison, supra note 2 , at $507-08$ ("[W]ith the narrowing of... general 
theory, increasingly relied on by plaintiffs in the wake of the at home trilogy, is consent-by-registration. ${ }^{6}$

Consent-by-registration is the idea that a corporation submits itself to general jurisdiction in a state by registering to do business in that state in compliance with a registration statute. ${ }^{7}$ The appeal of consent-byregistration to plaintiffs is readily apparent, as every state requires foreign corporations to register before conducting any business. ${ }^{8}$ Before the at home trilogy, lower courts were divided on whether consent-byregistration satisfied the Supreme Court's constitutional due process requirements for personal jurisdiction. ${ }^{9}$ After the trilogy, however, lower courts have increasingly rejected consent-by-registration as offending due process. ${ }^{10}$ Although the tide is turning against consent-by-

jurisdiction ... in Daimler, the natural next step for plaintiffs is to seek other grounds for general jurisdiction ...." (quotations omitted)); Norman H. Pentelovitch, Everyone's Favorite Legal Issue, MinN. LAW. (July 27, 2017), http://minnlawyer.com/2017/07/27/everyones-favorite-legal-issue/ [https://perma.cc/TU88

-WMCU] ("A trio of recent U.S. Supreme Court decisions has progressively narrowed the application of general personal jurisdiction.").

6. See Harrison, supra note 2, at 508 (stating that the most obvious place [for plaintiffs'] to look for new general jurisdiction theories is consent-by-registration (quotation omitted) (quoting Charles W. Rhodes \& Cassandra Burke Robertson, Toward A New Equilibrium in Personal Jurisdiction, 48 U.C. DAVIS L. REV. 207, 260 (2014))).

7. Because this Comment focuses on general jurisdiction, the phrase "consent-byregistration" refers only to situations where consent is applied to establish general jurisdiction. See Forest Labs., Inc. v. Amneal Pharm. LLC, No. 14-508-LPS, 2015 WL 880599, at *3 (D. Del. Feb. $26,2015)$ (discussing the plaintiff's "consent-by-registration" argument that a corporation "could validly consent to personal jurisdiction through compliance with ... . a state registration statute"); see also Harrison, supra note 2, at 516-38 (examining cases after Daimler accepting and rejecting "consent-by-registration").

Although this Comment uses the phrase consent-by-registration, it should be noted that many courts and legal commentators use other phrases with the same meaning. See Genuine Parts Co. v. Cepec, 137 A.3d 123, 136 (Del. 2016) (using "consent-based general jurisdiction" and "consent by registration"); Tanya J. Monestier, Registration Statutes, General Jurisdiction, and the Fallacy of Consent, 36 CARDOZO L. REV. 1343, 1347 (2015) ("registration-based general jurisdiction"); Rhodes \& Robertson, supra note 6, at 258 ("consent-based general jurisdiction").

8. See generally Kevin D. Benish, Note, Pennoyer's Ghost: Consent, Registration Statutes, and General Jurisdiction After Daimler AG v. Bauman, 90 N.Y.U. L. REV. 1609 app. (2015) (compiling every state's business registration statute and the consequences of registration in terms of personal jurisdiction).

The term "foreign corporation" in this Comment refers to any business not incorporated in a given state. A similar use of the term appears in the Supreme Court's recent general jurisdiction cases. See, e.g., Daimler, 571 U.S. at 127 (defining a "foreign" corporation as a "sister-state or foreign-country" corporation (quoting Goodyear Dunlop Tires Operations, S.A. v. Brown, 564 U.S. 915, $919(2011)))$.

9. See Harrison, supra note 2, at 512-16 (collecting the divided decisions of lower courts before Daimler on the issue of consent-by-registration).

10. Aspen Am. Ins. v. Interstate Warehousing, Inc., 90 N.E.3d 440, 445, 447 (Ill. 2017) (rejecting an interpretation of Illinois' registration statute that would subject foreign corporations to general jurisdiction as inconsistent with due process after Tyrrell); Segregated Account of Ambac 
registration in lower courts, conflicting opinions make the issue ripe for consideration by the Supreme Court. ${ }^{11}$

When the issue inevitably reaches the Supreme Court, the Court should defy expectations and hold that consent-by-registration comports with due process even after the at home trilogy. Part II of this Comment details the historical development of both general jurisdiction and consent-by-registration, reviewing the split authority among lower courts deciding consent-by-registration cases before and after the at home trilogy. Part III then develops an explicit consent approach to satisfy the fairness concerns of the plaintiffs' bar while also furthering the principles of the at home trilogy. Section III.A examines the arguments typically relied on by courts invalidating consent-by-registration and explains why these arguments do not apply to an explicit consent approach. Section III.B then submits that the Court never overturned its prior cases sanctioning consent-by-registration and argues that explicit consent continues to comport with due process after the at home trilogy.

\section{BACKGROUND}

Before developing an explicit consent approach to consent-byregistration, it is necessary to examine existing approaches to consentby-registration and the personal jurisdiction principles that govern them. This section provides a brief synopsis of the development of the general jurisdiction doctrine as it relates to business registration statutes and consent. First, Section II.A traces the evolution of the general jurisdiction doctrine over time by examining the Supreme Court's canonical opinions on the subject. Second, Section II.B introduces

Assurance Corp. v. Countrywide Home Loans, Inc., 898 N.W.2d 70, 76-79 (Wis. 2017) (same regarding a Wisconsin statute).

11. See Michael Huston, Sean Cooksey \& David Casazza, 'Consent' is the next big battle over personal jurisdiction, S.F. DAILY J. (July 5, 2017), https://www.gibsondunn.com/wpcontent/uploads/documents/publications/Huston-Cooksey-Casazza-Consent-is-the-next-big-battleover-personal-jurisdiction-DJ-7-5-2017.pdf [https://perma.cc/5CB7-PJCJ]; Gregg L. Weiner \& Adam M. Harris, 'Consent by Registration' Theory of Jurisdiction: Are Its Days Numbered?, N.Y. L.J. (Nov. 25, 2016), https://www.law.com/newyorklawjournal/almID/1202773180774/consent-byregistration-theory-of-jurisdiction-are-its-days-numbered/?back=law [https://perma.cc/WR3YYWJ2]

(discus

sing conflicting opinions among lower state and federal courts, and the potential for Supreme Court resolution of the issue); James J. Dries, BNSF and the Continuing Clarification of General Personal Jurisdiction, BAKER MCKENZIE (June 5, 2017), http:/www.bakermckenzie.com/en /insight/publications/2017/06/bnsf-general-personal-jurisdiction/ ("[I]n the aftermath of Goodyear and Daimler, the issue of consent jurisdiction has generated considerable debate in US courts, with inconsistent results .... This debate will continue until resolved by the US Supreme Court. Given the deep divisions that have arisen on this issue, it is reasonable to expect that the issue will soon come before the high court for review."). 
business registration statutes and their effect on personal jurisdiction, and later discusses the split authority among lower courts as to whether consent-by-registration comports with the due process requirements of general jurisdiction.

\section{A. The Court Awakens: General Jurisdiction Through the At Home Trilogy}

A court must have personal jurisdiction over the defendant before it can issue binding decisions on the merits. ${ }^{12}$ Operating as a restriction on the exercise of judicial power, personal jurisdiction recognizes a constitutionally protected liberty interest of the defendant under the Due Process Clause. ${ }^{13}$ The Supreme Court's early cases adopted a territorial view of judicial authority in which state courts only exercised personal jurisdiction over persons and property physically present within their borders. ${ }^{14}$ A territorial view of personal jurisdiction premised on state sovereignty prevailed until 1945, when the Court issued its seminal opinion on personal jurisdiction in International Shoe Co. $v$. Washington. ${ }^{15}$ After International Shoe, the Court's personal jurisdiction cases proceeded in two phases. In the first phase, two categories of personal jurisdiction emerged, and the Court permitted the vast expansion of general jurisdiction. In the second phase, the Court narrowed the test for general jurisdiction with its opinions in the at home trilogy cases. The remainder of this section traces the ebb and flow of general jurisdiction by discussing each phase separately.

12. Ruhrgas AG v. Marathon Oil Co., 526 U.S. 574, 577 (1999) ("Jurisdiction to resolve cases on the merits requires both authority over the category of claim in suit (subject-matter jurisdiction) and authority over the parties (personal jurisdiction), so that the court's decision will bind them."); 4 Charles Alan Wright et Al., Federal Practice \& Procedure $§ 1063$ (4th ed. 2015) (“A federal court may not proceed to a valid judgment in the absence of [personal jurisdiction] ....").

13. Ins. Corp. of Ir. v. Compagnie des Bauxites de Guinee, 456 U.S. 694, 702 (1982); see B. Travis Brown, Salvaging General Jurisdiction: Satisfying Daimler and Proposing a New Framework, 3 BELMONT L. REV. 187, 189 (2016) ("Jurisdiction is essentially the power of a court over persons and things. More specifically, personal jurisdiction is defined as a court's power to bring a person into its adjudicative process." (internal quotations and citations omitted)).

The Court first linked the personal jurisdiction requirements with the Due Process Clause in Pennoyer v. Neff, 95 U.S. 714, 733-34 (1877). See Harrison, supra note 2, at 483 ("[T] he critical analysis in Pennoyer rested upon linking the concept of personal jurisdiction with the constitutional requirements of the Fourteenth Amendment's Due Process Clause."); Benish, supra note 8, at 1615 (" $[P]$ ennoyer established the connection between personal jurisdiction and the Due Process Clause.").

14. Pennoyer, 95 U.S. at 720; Harrison, supra note 2, at 484 (describing an analysis "based on a defendant's physical presence and the territorial sovereignty of the states" as forming "the linchpin of courts' application of . . personal jurisdiction" in the years following Pennoyer).

15. 326 U.S. 310 (1945). 


\section{Phase One: The Expansion of General Jurisdiction}

The rapid industrialization of the United States economy at the turn of the twentieth century presented challenges for the territorial view of personal jurisdiction. ${ }^{16}$ Courts struggled to adapt the territorial view, which grounded personal jurisdiction on a defendant's physical presence in one state, with the reality that corporations were increasingly conducting business in more than one state. ${ }^{17}$ International Shoe directly addressed this tension between the realities of the new American economy and the territorial approach to personal jurisdiction.

In International Shoe, the Court pivoted from the territorial approach to personal jurisdiction to an analysis centered on the defendant's contacts with the forum state. ${ }^{18}$ International Shoe involved a suit in Washington against a Delaware corporation with its principal place of business in Missouri. ${ }^{19}$ Under the territorial view, the corporation claimed it was not present in Washington, and thus not subject to personal jurisdiction in Washington. ${ }^{20}$ The State of Washington, however, argued that Washington courts could exercise personal jurisdiction based on the corporation's in-state business activity. ${ }^{21}$ The Court affirmed Washington's exercise of personal jurisdiction and shifted the personal jurisdiction analysis away from physical presence and towards the relationship between the defendant, the forum, and the

16. See Edward D. Cavanagh, General Jurisdiction 2.0: The Updating and Uprooting of the Corporate Presence Doctrine, 68 ME. L. REV. 287, 290-91 (2016) (highlighting the invention of the automobile and accelerated pace of urbanization as "underscor[ing] the inadequacies of the common law's restrictive approach to personal jurisdiction"); Gwynne L. Skinner, Expanding General Personal Jurisdiction Over Transnational Corporations For Federal Causes of Action, 121 PeNN ST. L. REV. 617, 627 (2017) (comparing the ease of exercising jurisdiction over corporations under the territorial view in the eighteenth and nineteenth centuries with the difficulties of applying the territorial view in the industrialized twentieth century where corporations increasingly did business in many states).

17. See Harrison, supra note 2, at 484 ("As modern commerce developed in the twentieth century, business entities increasingly engaged in commerce in multiple states, including many states in which the business had no "presence' as that concept had been articulated in Pennoyer.").

18. Id. at 485 (observing the Court's movement in International Shoe beyond Pennoyer's "rigid requirement of physical presence" and articulation of "a new definition of "presence" premised on minimum contacts); Monestier, supra note 7, at 1349 ("[International Shoe] marked a shift away from the territoriality approach to jurisdiction that prevailed under Pennoyer... and ushered in a new era whereby minimum contacts became the touchstone of personal jurisdiction."); Benish, supra note 8, at 1616-17 (detailing the shift from due process limited by "the territorial borders of each state" under Pennoyer and towards due process limited by the defendant's in-state minimum contacts under International Shoe).

19. International Shoe, 326 U.S. at 312-13.

20. See id. at 315-16.

21. See id. at $313-15$. 
litigation. $^{22}$

The International Shoe Court created a new "minimum contacts" test for determining whether the exercise of personal jurisdiction over a nonresident corporation comports with due process:

[D]ue process requires only that in order to subject a defendant to a judgment in personam, if he be not present within the territory of the forum, he have certain minimum contacts with it such that the maintenance of the suit does not offend 'traditional notions of fair play and substantial justice.

In the decades following International Shoe, two categories of personal jurisdiction emerged: general and specific. ${ }^{24}$ A court may exercise specific jurisdiction when the suit "aris[es] out of or relate[s] to the defendant's contacts with the forum. ${ }^{, 25}$ Alternatively, a court may exercise general jurisdiction when a corporation's operations in the forum state are "so substantial and of such a nature as to justify suit against it on causes of action arising from dealings entirely distinct from those activities." ${ }^{26}$ Because this Comment focuses on consent-byregistration as a means of establishing general jurisdiction, the remainder of this section will examine the Court's general jurisdiction cases after International Shoe.

The Court decided only two general jurisdiction cases in the postInternational Shoe era before the at home trilogy-Perkins and Helicopteros. ${ }^{27}$ In those two cases, the Court required that a corporation

22. See id. at 319-20.

23. Id. at 316 (emphasis added) (quoting Milliken v. Meyer, 311 U.S. 457, 463 (1940)).

24. The distinction between general and specific jurisdiction first appeared in a law review article by two Harvard University professors. See Arthur T. von Mehren \& Donald T. Trautman, Jurisdiction to Adjudicate: A Suggested Analysis, 79 HARV. L. REV. 1121, 1136 (1966) (describing unlimited and limited general jurisdiction). The Court first recognized and adopted von Mehren and Trautman's general and specific distinction in two consecutive footnotes in Helicopteros Nacionales de Colombia, S.A. v. Hall. See 466 U.S. 408, 414 nn.8-9 (1984).

25. Daimler AG v. Bauman, 571 U.S. 117, 127 (2014) (alteration in original) (quoting Helicopteros, 466 U.S. at 414 n.8) (internal quotations omitted).

26. Id. (quoting International Shoe, 326 U.S. at 318).

27. The Court noted this trend towards specific jurisdiction in Daimler before summarizing the Court's two general jurisdiction cases. Id. at 128-31. In the first general jurisdiction case, Perkins v. Benguet Consolidated Mining Co., the Court examined a corporation's contacts in Ohio to determine if they were sufficient to satisfy due process. 342 U.S. 437, 445-46 (1952). The Court searched for "continuous and systematic" activities in Ohio that were "so substantial and of such a nature as to justify suit against it on causes of action arising from dealings entirely distinct from those activities." Id. (quoting International Shoe, 326 U.S. at 318). Because the defendant's Ohio contacts met that standard, the Court held that Ohio's exercise of general jurisdiction did not offend due process. Id. at 447-48. In the second general jurisdiction case, Helicopteros, the Court denied general jurisdiction in Texas after counting up all of the corporate defendant's contacts in Texas and 
have "continuous and systematic general business contacts" in a forum before being subjected to general jurisdiction. ${ }^{28}$ The Court's two general jurisdiction cases involved vastly different facts, and provided lower courts with little guidance regarding what kinds of business contacts in a state would satisfy the Court's contacts test. ${ }^{29}$ Lower courts during this period counted the corporate defendant's business activity in a forum in search of "continuous and systematic" contacts. ${ }^{30}$ Courts considered a wide menu of business activities in their search for continuous and systematic contacts, although the weight assigned to any given activity varied by jurisdiction. ${ }^{31}$ Lacking further clarification on how to evaluate corporate business contacts, lower courts vastly expanded the scope of general jurisdiction. $^{32}$ The vast expansion of available forums under International Shoe's contacts-based approach prevailed until Goodyear, the first installment of the at home trilogy.

\section{Phase Two: The At Home Trilogy}

In Goodyear Dunlop Tires Operations, S.A. v. Brown, ${ }^{33}$ the Court began narrowing the scope of general jurisdiction. ${ }^{34}$ Goodyear involved

determining that they were not sufficiently continuous and systematic to satisfy the minimum contacts analysis. 466 U.S. at 415-18.

28. Helicopteros, 466 U.S. at 416 (1984) (referencing Perkins, 342 U.S. at 445).

29. Patrick J. Borchers, The Problem with General Jurisdiction, 2001 U. CHI. LEGAL F. 119, 125 (2001) (observing that the Court's cases did not give "clear legal rules for contacts-based general jurisdiction”); Stanley E. Cox, The Missing “Why” of General Jurisdiction, 76 U. PITT. L. REV. 153, 158-59, 161-62 (2014) (arguing that the "vague and questionable" nature of the "continuous and systematic" business contacts test created confusion in lower courts); Richard D. Freer, Some Specific Concerns with the New General Jurisdiction, 15 NEV. L.J. 1161, 1166 (2015) (describing Perkins and Helicopteros as "nearly polar opposites on the scale of business activity in the forum" and explaining that "lower courts [have] wrestled with individual cases that presented much closer questions, without guidance from the Court.").

30. See Monestier, supra note 7, at 1352 n.45 (2015).

31. Lower courts during this era considered a variety of activities, such as "whether a corporation had a place of business in the forum, whether it had employees in the forum, whether it advertised to residents in the forum, its volume of sales in the forum, and so on." Id. at 1352 . However, courts did not balance these types of activities in the same way, which "meant that courts would come to different conclusions on whether they had general jurisdiction over defendants." Id. at $1352-53$.

32. See id. at $1353-54$.

33. 564 U.S. 915 (2011).

34. Monestier, supra note 7, at 1354 (describing Goodyear as "a case that ultimately marked the beginning of the end for doing business jurisdiction"); Benish, supra note 8, at 1618 (regarding Goodyear's reference to an "at home" test and focus on domicile, place of incorporation, and principal place of business as a "preview of the new era Daimler would usher in"); Craig Sanders, Note, Of Carrots and Sticks: General Jurisdiction and Genuine Consent, 111 NW. U. L. REV. 1323, 1327 (2017) (noting the Court's use of "essentially at home" in Goodyear as a "seemingly innocuous phrase tighten[ing] the reins on future general jurisdiction analyses"). 
a wrongful death claim filed in North Carolina by the parents of two boys killed in a bus accident in France against the Goodyear Tire Company and several of its foreign subsidiaries. ${ }^{35}$ The Goodyear subsidiaries' only contact was the exportation of a small percentage of their tires into the North Carolina market through the "stream of commerce." $" 36$ The North Carolina Supreme Court affirmed the exercise of general jurisdiction over the foreign subsidiaries because they manufactured products that eventually ended up in North Carolina, and therefore satisfied International Shoe's minimum contacts test. ${ }^{37}$

The United States Supreme Court rejected North Carolina's stream of commerce approach to general jurisdiction. ${ }^{38}$ The Court first stated that the appropriate general jurisdiction forum for individuals is their place of domicile, whereas for corporations, "it is an equivalent place, one in which the corporation is fairly regarded as at home." 39 The Court then identified the place of incorporation and principal place of business as paradigm examples of a corporation's home forum. ${ }^{40}$ Because the

35. Goodyear, 564 U.S. at 918. The parents in the case argued that the bus's tires were defective and named as defendants the parent corporation-Goodyear USA, an Ohio corporation which did not contest general jurisdiction in North Carolina - and three of Goodyear USA's foreign subsidiaries. Id. at 920-21. The Goodyear subsidiaries were incorporated and held their principal places of business outside the United States. Id.

36. Id. at 921 .

37. Id. at 926 .

38. Id. at 929

39. Id. at 924 (emphasis added).

40. Id. The Court listed these "paradigm examples" in a parenthetical, but it did not clarify if these were the only forums where courts should consider corporations "at home" or whether the Court intended the at home inquiry to replace International Shoe's minimum contacts analysis.

Legal commentators were critical of the Court's failure to clearly articulate the meaning of the at home inquiry in Goodyear. See Cox, supra note 29, at 167 (arguing that "it was hardly clear how much ... might be required to make a corporation "at home"" and that the Court "failed to provide clear rules or a deeper explanation for what lay behind the 'at home' gloss"); Meir Feder, Goodyear, "Home," and the Uncertain Future of Doing Business Jurisdiction, 63 S.C. L. REV. 671, 672 (2012) (debating the effects of Goodyear and noting that, given the significant implications of the new at home test, some commentators argued "[the implications] cannot have been intendedthat the Court's apparent restriction of general jurisdiction... should be dismissed as 'loose language,' and that Goodyear should be limited to its 'particular facts"'); Harrison, supra note 2, at 499 ("The Court in Goodyear did not expressly limit general jurisdiction to a corporation's state of incorporation or its principal place of business."); Monestier, supra note 7, at 1355 (indicating that "[c]learly, the 'at home' language was intended to mean something," but that legal scholars and courts were unsure if the Court "intended to make a sweeping change to general jurisdiction with just [those] two words"); Kaitlin Hanigan, Comment, A Blunder of Supreme Proportions: General Jurisdiction After Daimler AG v. Bauman, 48 LOY. L.A. L. REV. 291, 296 (2014) (arguing that although the Goodyear Court established a new "at home" standard, "the Court did not entirely flesh out the concept" or provide guidance to lower courts because the Court "suggested that a company could be 'essentially at home' outside of its state of incorporation or principal place of business, but provided no example for lower courts"). 
Goodyear subsidiaries were incorporated and headquartered elsewhere, they were not at home in North Carolina and thus lacked the continuous and systematic business contacts required to permit North Carolina courts to hear a cause of action arising outside North Carolina. ${ }^{41}$ The Court held that the entrance of the Goodyear subsidiaries' tires into North Carolina through the stream of commerce did not create general jurisdiction because the subsidiaries were not at home in North Carolina. $^{42}$

The second case in the trilogy continued Goodyear's restriction of general jurisdiction. In Daimler $A G$ v. Bauman, twenty-two Argentinian residents sued a German corporation in California seeking damages for acts committed by the corporation's Argentinian-subsidiary in Argentina. ${ }^{43}$ The Argentinian plaintiffs sought general jurisdiction in California over the German corporation based on the distribution of its products in the state by a U.S. subsidiary incorporated in Delaware with its principal place of business in New Jersey. ${ }^{44}$

The Court rejected California's exercise of general jurisdiction because the German corporation did not incorporate or hold its principal place of business in California. ${ }^{45}$ Even assuming the U.S. subsidiary's California contacts were attributable to the German corporation, those contacts did not make the German corporation at home in California. ${ }^{46}$ The Court repeated Goodyear's domicile standard that general jurisdiction requires affiliations with a forum "so "continuous and systematic' as to render [the defendant] essentially at home in the forum State." 47 The Court confirmed that this meant a corporation could only be subject to general jurisdiction in its state of incorporation and principal place of business. ${ }^{48}$ However, the Court reserved the possibility of an "exceptional case" arising where a corporation could be subject to general jurisdiction outside its state of incorporation and principal place of business but did not elaborate further. ${ }^{49}$ The Court

\footnotetext{
41. Goodyear, 564 U.S. at 929.

42. $I d$.

43. Daimler AG v. Bauman, 571 U.S. 117, 120-21 (2014).

44. Id. at 121 .

45. Id. at $138-39$.

46. Id. at 136 ("Even if we were to assume that MBUSA is at home in California, and further to assume MBUSA's contacts are imputable to Daimler, there would still be no basis to subject Daimler to general jurisdiction in California, for Daimler's slim contacts with the State hardly render it at home there.").

47. Id. at 139 (quoting Goodyear, 564 U.S. at 919).

48. Id.

49. Id. at 139 n. 19 .
} 
ultimately held that because the German corporation was neither incorporated nor headquartered in California, and therefore not at home in California, California courts could not exercise general jurisdiction. ${ }^{50}$

The final trilogy case, BNSF Railway Co. v. Tyrrell, confirmed that Daimler and Goodyear's at home test applied to all state court assertions of general jurisdiction. ${ }^{51}$ The Tyrrell plaintiffs sued a Delawareincorporated, Texas-headquartered railroad in Montana state court after sustaining work-related injuries outside Montana. ${ }^{52}$ The plaintiffs argued that Montana state courts had general jurisdiction based on the railroad's in-state business activities, while the railroad countered that general jurisdiction could not be based on those contacts because the railroad was not at home in Montana. ${ }^{53}$ The Montana courts affirmed the exercise of general jurisdiction because the at home test did not apply to cases involving a defendant railroad or the plaintiffs' particular injury claims. ${ }^{54}$

The Court reversed Montana's decision to exercise general jurisdiction as contrary to the at home test. ${ }^{55}$ The Court rejected the contention that Daimler applied only to specific types of claims against particular defendants, stating that "[t]he Fourteenth Amendment due process constraint described in Daimler... applies to all state-court assertions of general jurisdiction over nonresident defendants." ${ }^{56}$ Because the railroad was not incorporated or headquartered in Montana, the railroad was not at home, and Montana's exercise of general jurisdiction offended due process. ${ }^{57}$ Notably, the Court declined to consider an argument that the railroad consented to general jurisdiction in Montana by registering to do business there because the court below did not reach the issue. ${ }^{58}$ In other words, the Court left unanswered the question of whether consent-by-registration continues to satisfy due process.

Justice Sotomayor's Tyrrell dissent criticized the majority's

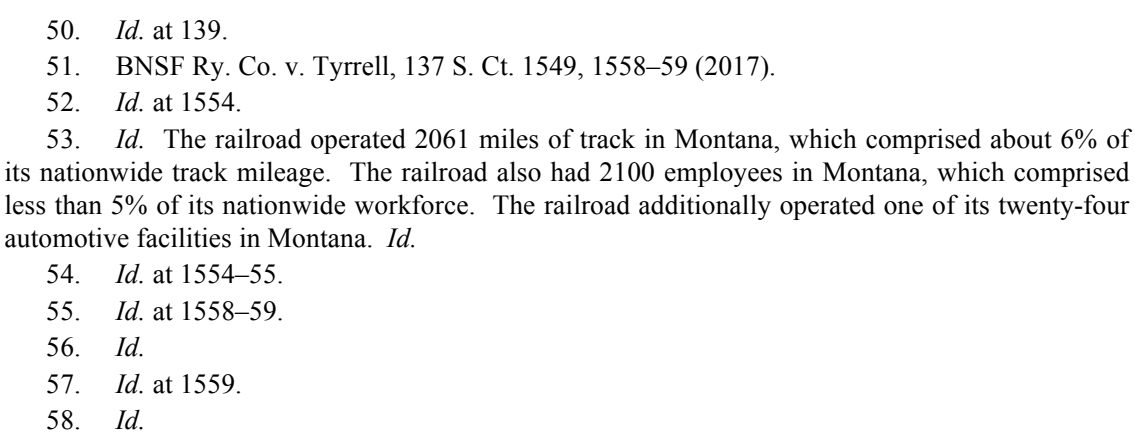


continued use of the at home test and deviation from International Shoe's minimum contacts analysis. ${ }^{59}$ She argued that the at home test places significant burdens on individual plaintiffs:

The majority's approach grants a jurisdictional windfall to large ... corporations that operate across many jurisdictions.... [I]t is virtually inconceivable that such corporations will ever be subject to general jurisdiction in any location other than their principal places of business or of incorporation.... [A] holistic, nuanced contacts analysis ... has now effectively been replaced by the rote identification of a corporation's principal place of business or place of incorporation. The result? It is individual plaintiffs, harmed by the actions of a farflung foreign corporation, who will bear the brunt of the majority's approach and be forced to sue in distant jurisdictions with which they have no contacts or connection. ${ }^{60}$

Justice Sotomayor also criticized the majority's treatment of the "exceptional cases" reserved in Daimler. ${ }^{61}$ The majority appeared to limit the scope of the exception to the exact facts of Perkins, a limitation which would arguably "read the exception out of existence entirely." 62 Instead of applying the at home test, Justice Sotomayor would have remanded the case to the Montana Supreme Court to determine whether the railroad's contacts fit the "exceptional case" described in Daimler. ${ }^{63}$

Altogether, the at home trilogy of Goodyear, Daimler, and Tyrrell effectively replaced International Shoe's minimum contacts analysis with a formulaic at home test based solely on the state of incorporation and principal place of business. The trilogy decisively narrowed the scope of corporate general jurisdiction and left lingering questions regarding the continued validity of once widely recognized jurisdictional practices. One such practice is consent-by-registration. Having traced the evolution of the Court's general jurisdiction doctrine, the next section examines business registration statutes, their use as a means of obtaining consent to general jurisdiction, and the split authority regarding the continued constitutionality of consent-by-registration after the at home trilogy.

59. Id. at 1560 (Sotomayor, J., concurring in part and dissenting in part). Justice Sotomayor agreed with the majority's conclusion that $\S 56$ of the Federal Employee Liability Act did not create jurisdiction but disagreed with the majority's application of the at home test and the decision to reverse the Montana Supreme Court instead of remanding to determine if the case fell under the "exceptional case" exception described in Daimler. Id. at 1560, 1562.

60. Id. at $1560-61$ (citations and footnotes omitted).

61. Id. at $1561-62$.

62. Id.

63. Id. 


\section{B. Plaintiff Strikes Back: Consent-By-Registration}

Every state, by statute, requires foreign corporations to register before conducting any business in that state. ${ }^{64}$ Registration entails filing an application with the Secretary of State containing the name and address of a designated in-state agent for service of process. ${ }^{65}$ States which recognize consent-by-registration take the act of designating an instate service agent as the foreign corporation's agreement that it may be subject to personal jurisdiction in that state. ${ }^{66}$ Pennsylvania's long-arm statute, for example, expressly states that a corporation's registration will be taken as consent to general jurisdiction in Pennsylvania courts. ${ }^{67}$ The Pennsylvania approach is an example of explicit consent-byregistration. $^{68}$ Unlike Pennsylvania, most registration and long-arm statutes are silent on the issue of consent and speak only to service of process. $^{69}$ Nonetheless, the courts of several states interpret their registration statutes to have the same effect as Pennsylvania's express

64. Kansas, for example, requires that "[b]efore doing business in the state ... a foreign covered entity shall register with the secretary of state.” KAN. STAT. ANN. § 17-7931 (Supp. 2017). Section 17-7931(a)-(h) of the Kansas statute then lists all the information which a registering organization must include in its application for registration. See generally Benish, supra note 8, at app. (providing an overview and citation to every state's business registration statute and the consequence of registration in terms of personal jurisdiction).

65. The Kansas registration statute requires that a foreign corporation's application include "the address of the registered office and the name and address of the resident agent for service of process required to be maintained by this act." KAN. STAT. ANN. § 17-7931(f).

66. See generally Harrison, supra note 2, at 516-30 (describing the rationale of post-Daimler cases holding that corporate registration entails consent to general jurisdiction).

67. Pennsylvania's approach is an example of explicit consent-by-registration. Pennsylvania's foreign registration statute, 15 PA. STAT. AND CONS. STAT. ANN. § 411(b)-(e) (Westlaw through 2018 Sess.), simply lists the requirements of registering as a foreign business in Pennsylvania. However, the Pennsylvania long-arm statute explicitly states that registering to do business as a foreign corporation establishes consent by the corporation to general jurisdiction. 42 PA. STAT. AND CONS. Stat. ANN. $§ 5301$ (West 2004). The Pennsylvania long-arm statute says that "[t]he existence of any of the following relationships between a person and [Pennsylvania] shall constitute a sufficient basis of jurisdiction to enable the tribunals of [Pennsylvania] to exercise general personal jurisdiction over such person ... and to enable such tribunals to render personal orders against such person." Id. at $\S 5301$ (a). One of the relationships that follows the general provision in $\S 5301$ (a) is "qualification as a foreign corporation under the laws of this Commonwealth." Id. at § 5301(a)(2)(i). Pennsylvania is the only state with a statute that expressly conditions registration on consent to general jurisdiction. See Monestier, supra note 7, at 1366-68.

68. Sanders, supra note 34, lays out the basic difference between explicit and implicit consentby-registration. Explicit consent-by-registration, like the scheme adopted in Pennsylvania, "explicitly condition[s] consent as part of the registration." Id. at 1334. Implicit consent-byregistration, on the other hand, occurs where a state's courts "read in implied consent simply by virtue of a corporation registering within a state (harkening back to constructive consent based on fictional presence)." Id. at 1334-35.

69. See Benish, supra note 8, at app. 
statute. $^{70}$ These states have enacted implicit consent-by-registration schemes. ${ }^{71}$ After the at home trilogy, many plaintiffs turned to consentby-registration as an alternative means of obtaining general jurisdiction over corporate defendants. ${ }^{72}$ With these statutory schemes in mind, the remainder of Section II.B details the split among lower courts before and after the at home trilogy on whether consent-by-registration satisfies due process.

\section{Lower Court Split Before the At Home Trilogy}

The United States Supreme Court issued several opinions on registration and consent to general jurisdiction prior to International Shoe. In the nineteenth century, the Court held that states could condition foreign corporate registration on consent to specific

70. See id. (collecting state registration statutes and cases interpreting these statutes to determine the jurisdictional consequences of corporate registration). The Kansas Supreme Court, for example, has interpreted the Kansas foreign corporation registration statute as subjecting the applicant to general jurisdiction in Kansas. Merriman v. Crompton Corp., 146 P.3d 162, 171 (Kan. 2006) (interpreting a prior version of the Kansas registration statute). The Kansas registration statute requires that a registration-to-do-business application submitted by a foreign corporation must include "the name and address of the resident agent for service of process" and also "an irrevocable written consent of the foreign covered entity that actions may be commenced against it in the proper court of any county where there is proper venue by the service of process." KAN. STAT. ANN. § 177931(f)-(g). Some commentators argue that the replacement of the old statute implicates the Kansas Supreme Court's conclusion that the registration statute explicitly requires consent to general jurisdiction as a condition of doing business in Kansas. See Monestier, supra note 7, at $1368 \mathrm{n} .121$ ("The Kansas statute at issue in Merriman has since been repealed and replaced by section 177931(a)(7). This statute also does not explicitly state the jurisdictional consequences associated with registering to do business in Kansas."). However, the Kansas courts continue to accept the same interpretation of $\S 17-7931$ as they did for the statute at issue in Merriman. See, e.g., Kearns v. N.Y. Cmty. Bank, No. 115,470, 2017 WL 1148418, at *5 (Kan. Ct. App. Mar. 24, 2017) (per curiam) (interpreting the new registration statute as "provid[ing] a basis for Kansas courts to exercise general jurisdiction over foreign corporations" (citing Merriman)).

71. See Brown v. Lockheed Martin Corp., 814 F.3d 619, 640 (2d Cir. 2016) (discussing an interpretation of Connecticut's statute which treats "mere registration and the accompanying appointment of an in-state agent-without an express consent to general jurisdiction-nonetheless suffic[ient] to confer general jurisdiction by implicit consent").

72. See Harrison, supra note 2 , at 507-08 ("[W]ith the narrowing of...general jurisdiction ... in Daimler, 'the natural next step for plaintiffs is to seek other grounds for general jurisdiction, and the most obvious place to look ... is in a state registration filing that designates a corporate agent for service of process." (quoting Rhodes \& Robertson, supra note 6, 259-60)); Monestier, supra note 7, at 1358 ("[N]ow that plaintiffs will have a much harder time establishing general jurisdiction over defendants ... a different ground of jurisdiction will most certainly take center stage: that of corporate registration. Plaintiffs who are foreclosed ... under the Daimler "at home" standard will recast their jurisdictional analysis and ... premise general jurisdiction on a corporation's act of registering to do business ...." (footnotes omitted)); Benish, supra note 8, at 1610-11 (arguing that Daimler's elimination of long-held bases of personal jurisdiction "spark[ed a] search for alternative means to establish general jurisdiction over foreign corporations" which resulted in consent-by-registration being "the go-to alternative to Daimler's holding"). 
jurisdiction. ${ }^{73}$ Then in Pennsylvania Fire Insurance Co. of Philadelphia v. Gold Issue Mining \& Milling Co., the Court held that Missouri validly exercised personal jurisdiction on a cause of action arising outside Missouri on the basis of consent-by-registration. ${ }^{74}$ The Court cited Pennsylvania Fire four years later when it held that a state's interpretation of its own registration statute determines the jurisdictional effect of registration, ${ }^{75}$ and again eighteen years later when it held that the voluntary act of registration constitutes "real consent" to jurisdiction. $^{76}$ So at least before International Shoe, the Court recognized that a state could require consent to general jurisdiction as a condition of registering to do business in the state.

Following International Shoe, the federal circuits split on whether the Court had invalidated the practice of consent-by-registration. ${ }^{77}$ The

73. See St. Clair v. Cox, 106 U.S. 350, 356 (1882) ("The state may ... impose as a condition upon which a foreign corporation shall be permitted to do business within her limits, that it shall stipulate that in any litigation arising out of its transactions in the state, it will accept as sufficient the service of process on its agents ... and the condition would be eminently fit and just. And such condition . . may be implied as well as expressed." (emphasis added)); Lafayette Ins. Co. v. French, 59 U.S. 404, 407-08 (1855) (same).

74. 243 U.S. 93, 94-95 (1917). The plaintiff in Pennsylvania Fire sued a foreign corporation in Missouri on a cause of action not arising in Missouri and sought jurisdiction based on Missouri's registration statute that required foreign corporations to appoint an in-state agent for service of process. Id. at 94. Missouri's courts interpreted their statute as establishing consent to personal jurisdiction, even on claims not arising in Missouri. Id. at 95. Although the decision pre-dates the distinction between general and specific jurisdiction, courts today would consider this case a general jurisdiction case because the cause of action arose outside of the forum. Specifically, the plaintiff's claim involved buildings in Colorado that the plaintiff owned and the defendant had insured. Id. at 94. The Court ultimately held that Missouri could exercise personal jurisdiction consistent with due process because the foreign corporation chose to do business in Missouri, and thus took "the risk of the interpretation ... put upon [the state] by [Missouri's] . . courts." Id. at 96.

75. Robert Mitchell Furniture Co. v. Selden Breck Const. Co., 257 U.S. 213, 216 (1921) (holding that compliance with a registration statute and appointment of a registered service agent may not establish jurisdiction on causes of action arising outside the forum " $[u]$ nless the state law either expressly or by local construction gives to the appointment a larger scope" (emphasis added)). See also, Harrison, supra note 2, at 511 (discussing Robert Mitchell as the Court "clari[fying] its holding in Pennsylvania Fire and explain[ing] that federal courts should first look to how state courts have interpreted state registration statutes to determine whether a corporation's compliance with the statute grants ... personal jurisdiction over the corporation").

76. Neirbo Co. v. Bethlehem Shipbuilding Corp., 308 U.S. 165, 174-75 (1939). Although Neirbo involved objection to venue and not personal jurisdiction, there is not any "reason why the same logic would not apply to the question of what amounts to 'actual consent' to personal jurisdiction." Forest Labs., Inc. v. Amneal Pharm. LLC, No. 14-508-LPS, 2015 WL 880599, at *8. (D. Del. Feb. 26, 2015).

77. Compare Bane v. Netlink, Inc., 925 F.2d 637, 641 (3d Cir. 1991) (affirming general jurisdiction based on Pennsylvania's consent-by-registration statute), and Knowlton v. Allied Van Lines, Inc., 900 F.2d 1196, 1200 (8th Cir. 1990) (holding that a foreign corporation's compliance with Minnesota's registration statute constituted consent to general jurisdiction in Minnesota in satisfaction of due process), with Wenche Siemer v. Learjet Acquisition Corp., 966 F.2d 179, 18384 (5th Cir. 1992) (rejecting general jurisdiction based on Texas' registration statute on a theory of 
Court in International Shoe first mentioned consent when describing what is now recognized as specific jurisdiction, ${ }^{78}$ and then again when discussing its prior cases as resorting to the "legal fiction that [a corporation] has given its consent to service and suit, consent being implied from its presence in the state through the acts of its authorized agents." ${ }^{79}$ Two federal circuits after International Shoe held that consent-by-registration remained consistent with due process. ${ }^{80}$ Two other circuits expressed support for consent-by-registration, though neither expressly held that the practice met constitutional due process requirements. ${ }^{81}$ Four circuits had not issued opinions on consent-by-

consent because "it would be violative of due process"), and Wilson v. Humphreys (Cayman) Ltd., 916 F.2d 1239, 1245 (7th Cir. 1990) (declining to interpret compliance with Indiana's registration statute as consenting a foreign corporation to general jurisdiction in Indiana because such an interpretation "cannot satisfy ... the demands of due process" and would render the statute "constitutionally suspect"). See generally Benish, supra note 8, at 1611 tbl.1 (providing a representation of the position taken in each federal circuit court of appeals and the cases that accompany those positions).

78. 326 U.S. 310, 317 (1945) ("'Presence' in the state in this sense has never been doubted when the activities of the corporation there have not only been continuous and systematic, but also give rise to the liabilities sued on, even though no consent to be sued or authorization to an agent to accept service of process has been given." (emphasis added)).

79. Id. at 318 .

80. Bane, 925 F.2d at 641 (finding personal jurisdiction in Pennsylvania over a foreign corporate defendant registered to do business in compliance with Pennsylvania's statute because "[c]onsent is a traditional basis for... jurisdiction long upheld as constitutional" and because the Pennsylvania statute "gave [the defendant] notice that [it] was subject to personal jurisdiction in Pennsylvania and thus it should have been reasonably able to anticipate being haled into court in Pennsylvania" (internal quotations omitted) (quoting Provident Nat'l Bank v. Cal. Fed. Sav. \& Loan Ass'n, 819 F.2d 434, 437 (3d Cir. 1987))"; Knowlton, 900 F.2d at 1200 (holding that the defendant consented to general jurisdiction in Minnesota by registering to do business and appointing an agent for service of process because the Minnesota Supreme Court had interpreted the statute to give rise to general jurisdiction and because the practice was a "traditionally recognized and well-accepted species of general consent"); see also Benish, supra note 8, at 1612 (listing the approach taken by each Circuit before Daimler).

81. In Spiegel v. Schulmann, for instance, the Second Circuit in a footnote expressed support for consent-by-registration. 604 F.3d 72, 77 n.1 (2d Cir. 2010). The Second Circuit indicated that the contention that the defendant in the case was subject to general jurisdiction by registering to do business in New York "would have been sufficient to establish personal jurisdiction." Id. However, the Second Circuit did not consider that argument because the plaintiffs did not raise it before the district court. Id. The Ninth Circuit also signaled its support for consent-by-registration in a decision rendered a few months before the Goodyear decision. King v. Am. Family Mut. Ins. Co., 632 F.3d 570 (9th Cir. 2011). In King, the Ninth Circuit agreed that a corporation's registration to do business could be taken as consent to general jurisdiction but concluded that the Montana state courts interpreting the particular registration statute at issue in that case did not impute such an interpretation onto their statute. Id. at 576-78 (holding that because Robert Mitchell instructed the court to look at the state's interpretation of its registration statute and because Montana did not interpret their statute as "standing alone, subject[ing] foreign corporations to jurisdiction in Montana for acts performed outside of Montana," Montana could not exercise general jurisdiction over the defendant). 
registration before the at home trilogy, ${ }^{82}$ and at least three others rejected consent-by-registration arguments. ${ }^{83}$ In sum, before Goodyear, Daimler, and Tyrrell, the federal courts of appeals were split on whether consentby-registration constituted a valid basis for the assertion of general jurisdiction.

\section{Lower Court Trends During and After the At Home Trilogy}

Although the at home trilogy never addressed consent-byregistration, the trilogy nevertheless resulted in a discernable shift away from consent-by-registration in lower courts. The vast majority of courts after Daimler hold that consent-by-registration offends due process under the new at home test and may no longer provide an independent basis for establishing general jurisdiction. ${ }^{84}$ A few courts, however, maintain that the Supreme Court never overturned Pennsylvania Fire's sanctioning of consent-by-registration, and the practice therefore continues to satisfy due process even under the more rigid standards imposed by the at home trilogy. ${ }^{85}$ This section samples a few of the significant consent-byregistration cases which account for the at home trilogy to demonstrate

82. The Sixth, Tenth, D.C. and Federal Circuits had not issued opinions on the issue of consent-by-registration before Goodyear. See Benish, supra note 8, at 1611 tbl.1.

83. Consol. Dev. Corp. v. Sherritt, Inc., 216 F.3d 1286, 1293 (11th Cir. 2000) (rejecting a consent-by-registration argument because "[t]he casual presence of a corporate agent in the forum is not enough to subject the corporation to suit where the cause of action is unrelated to the agent's activities" (citing International Shoe Co. v. Washington, 326 U.S. 310, 317 (1945))); Wilson v. Humphreys (Cayman) Ltd., 916 F.2d 1239, 1245 (7th Cir. 1990) (holding that an interpretation of Indiana's registration statute which found compliance alone created general jurisdiction "[could not] satisfy ... the demands of due process"); Ratliff v. Cooper Labs., Inc., 444 F.2d 745, 748 (4th Cir. 1971) (holding that registration and appointment of an agent for service of process under South Carolina law did not "tip the scale" in the plaintiff"s favor and giving that fact "no special weight" in the court's minimum contacts analysis under International Shoe). As some courts note, however, it is not clear that these courts were rejecting a consent argument. See Forest Labs., Inc. v. Amneal Pharm. LLC, No. 14-508-LPS, 2015 WL 880599, at *9 (D. Del. Feb. 26, 2015) ("[N] one of [the three Circuit opinions] directly address the issue of consent-i.e., why compliance with such a statute could not, under any circumstances, amount to the kind of consent to jurisdiction referenced in Pennsylvania Fire, Robert Mitchell, and Neirbo.").

84. James M. Beck, 50 State Survey On General Jurisdiction Through Consent By Registration To Do Business: Putting Bauman and Baseball Back Together, DRUG \& DEVICE L. (Dec. 18, 2017), https://www.druganddevicelawblog.com/2017/12/quasi-guest-post-50-state-surveyon-general-juris

diction-through-consent-by-registration-to-do-business-putting-bauman-and-baseball-back-together .html [https://perma.cc/MH3S-7RWE] (collecting cases after Daimler and concluding that "[t]he overwhelming number of state and federal decisions... shows an unmistakable trend against subjecting a nonresident defendant to a state's general jurisdiction through registration for business").

85. See Acorda Therapeutics Inc. v. Mylan Pharm. Inc., 817 F.3d 755, 765-70 (Fed. Cir. 2016) (O’Malley, J., concurring). 
the trend towards the invalidation of consent-by-registration.

The Second Circuit rejected implicit consent-by-registration in Brown v. Lockheed Martin Corp. ${ }^{86}$ Brown concerned a challenge to Connecticut's registration statute, which does not mention personal jurisdiction and speaks only to service of process. ${ }^{87}$ Because the defendant clearly did not fit the at home test, the plaintiff relied on the defendant's registration as a foreign corporation to supply general jurisdiction. $^{88}$ The Second Circuit declined to exercise general jurisdiction on the basis of the defendant's registration to do business, concluding that interpreting Connecticut's statute as requiring consent to general jurisdiction, where the text spoke only to service of process, violated the due process principles articulated in Goodyear and Daimler. ${ }^{89}$ Such an interpretation would subject corporations to suit in every state because every state has a registration statute requiring appointment of a service agent. ${ }^{90}$ Because Daimler rejected such an "exorbitant exercise" of general jurisdiction, that interpretation would violate due process. ${ }^{91}$ Therefore, the Second Circuit rejected the exercise of general jurisdiction in Connecticut on the basis of consent-byregistration. $^{92}$

The Second Circuit exempted explicit consent-by-registration from its narrow holding interpreting Connecticut's implicit statutory scheme. The court held only that the particular interpretation of Connecticut's statute violated due process, an interpretation which implied consent from the text of a statute which itself said nothing about consent. ${ }^{93}$ Throughout its opinion, the court emphasized that a case of explicit consent spelled out unambiguously in a registration statute would present a different issue. $^{94}$ In fact, the Second Circuit dedicated an entire

86. 814 F.3d 619 (2d Cir. 2016).

87. Id. at 622 ("[T] he terms of [Connecticut's] registration and appointment statutes are unclear as to whether they purport to confer on the state's courts the power to exercise general jurisdiction over duly registered foreign corporations.").

88. Id. The Maryland-incorporated defendant maintained its principal place of business in Maryland and was thus not at home in Connecticut. Id.

89. Id. at $639-40$.

90. Id. at 640 .

91. Id. at 639-40.

92. Id. at 641 .

93. See id. at 637 (comparing the interpretation of Connecticut's registration statute by its appellate courts with the explicit language claiming consent to general jurisdiction in Pennsylvania's long-arm statute).

94. Id. at 637-41. The court noted "[t]he Connecticut statute, in contrast [to Pennsylvania's statute], gives no notice to a corporation registering to do business in the state that the registration might have the sweeping effect [of the corporation consenting to general jurisdiction]." Id. at 637. 
paragraph to distinguishing between Connecticut's implicit consent scheme and the explicit statutory consent approach taken in other jurisdictions:

Were the Connecticut statute drafted such that it ... requir[ed] foreign corporations to consent to general jurisdiction, we would be confronted with a more difficult constitutional question about the validity of such consent after Daimler.... [S]ome of our sister circuits have upheld states' determinations that... registration to do business constitutes consent to the exercise of general jurisdiction.... [I]t could be concluded that a carefully drawn state statute that expressly required consent to general jurisdiction as a condition on a foreign corporation's doing business in the state ... might well be constitutional.

Consequently, the Second Circuit in Brown clearly preserved the possibility of explicit statutory consent remaining a viable means of obtaining general jurisdiction even after the Supreme Court's adoption of the narrow at home test.

Shortly after Brown, the Federal Circuit also considered the issue of consent-by-registration in Acorda Therapeutics Inc. v. Mylan Pharmaceuticals Inc. ${ }^{96}$ Acorda involved both a general and specific jurisdiction argument, although the majority opinion only addressed specific jurisdiction. ${ }^{97}$ In a concurring opinion, Judge O'Malley concluded that the court need not reach the specific jurisdiction issue because the defendant consented to general jurisdiction. ${ }^{98}$ Judge O'Malley's concurrence discussed Supreme Court cases affirming the defendant's right to waive objection to personal jurisdiction and consent to suit in a forum as evidence of the continuing viability of consent. ${ }^{99}$ The concurrence also argued that the Supreme Court never expressly overturned Pennsylvania Fire despite having numerous occasions to do

The Second Circuit also concluded, after examining Pennsylvania Fire's continued use of Daimler, that "mere registration ... without an express consent to general jurisdiction ... would ... subject [every corporation] to general jurisdiction in every state in which it registered, and Daimler's ruling would be robbed of meaning by a back-door thief." Id. at 640 (emphasis added).

95. Id. at $640-41$.

96. 817 F.3d 755 (Fed. Cir. 2016).

97. Id. at 757 (affirming the district court's finding of specific jurisdiction and "not address[ing] the issue of general personal jurisdiction").

98. Id. at 764-65 (O'Malley, J., concurring) ("The specific jurisdiction issue, which the majority exclusively decides, is a more difficult question ... than the ... continuing precedential effect of . . Pennsylvania Fire ....").

99. Id. at 765-66 ("[B]ecause the personal jurisdiction requirement is a waivable right, there are a 'variety of legal arrangements' by which a litigant may give 'express or implied consent to the personal jurisdiction of the court."' (quoting Burger King Corp. v. Rudzewicz, 471 U.S. 462, 472 n.14 (1985))). 
so. ${ }^{100}$ Judge O'Malley also found the absence of a discussion about consent-by-registration in Daimler significant because Daimler's only reference to consent distinguished consent cases from the at home test. ${ }^{101}$

Relying on Pennsylvania Fire and its progeny, Judge O'Malley looked to Delaware's interpretation of its statute, which construed registration as consent, and argued that the defendant consented to general jurisdiction in Delaware by registering to do business and appointing an agent for service of process. ${ }^{102}$

In addition to Brown and Judge O'Malley's Acorda concurrence, several other lower courts have decided consent-by-registration cases after the at home trilogy. The Fifth, Ninth, and Eleventh Circuits recently issued opinions on consent-by-registration, ${ }^{103}$ and the Second Circuit will decide another consent-by-registration case in the near

100. Id. at 768. Judge O'Malley detailed the numerous occasions when the Court was faced with a chance to reject Pennsylvania Fire's sanctioning of consent-by-registration, "[y]et each time the issue arose, the Supreme Court reaffirmed that registration statutes, mandatory for doing business, could confer jurisdiction through consent depending on the interpretation given to those state statutes by state courts." Id. (citing Neirbo Co. v. Bethlehem Shipbuilding Corp., 308 U.S. 165, 175 (1939); Louisville \& N.R. Co. v. Chatters, 279 U.S. 320, 329 (1929); Robert Mitchell Furniture Co. v. Selden Breck Constr. Co., 257 U.S. 213, 216 (1921)). Judge O’Malley also noted that even after International Shoe, the Court did not overrule Pennsylvania Fire. Id. at 768-69.

101. Id. at 769. As Judge O'Malley pointed out, the Court's sole mention of consent in Daimler potentially signals the continuing viability of consent-by-registration. Id. (noting that Perkins v. Benguet Consol. Mining Co., 342 U.S. 437 (1952), remains "the textbook case of general jurisdiction appropriately exercised over a foreign corporation that has not consented to suit in the forum" (quoting Daimler AG v. Bauman, 571 U.S. 117, 129 (2014)).

102. Acorda, 817 F.3d at 769-70. When Judge O'Malley penned her concurrence, the controlling Delaware Supreme Court case interpreting the Delaware registration statute was Sternberg v. O'Neil, 550 A.2d 1105 (Del. 1988), which interpreted the statute as conferring consent to general jurisdiction. Exactly one month after Judge O'Malley's Acorda concurrence, the Delaware Supreme Court overturned its interpretation of the Delaware registration statute in Genuine Parts Co. v. Cepec, 137 A.3d 123 (Del. 2016). Cepec concluded that Sternberg's interpretation of the Delaware statute as establishing consent to general jurisdiction was too farreaching and no longer comported with due process in light of Goodyear and Daimler's at home standard. Id. at 127-28.

103. A Fifth Circuit panel in Gulf Coast Bank \& Trust Co. v. Designed Conveyor Systems, L.L.C. declined to decide whether consent-by-registration offends due process because it concluded that Louisiana law does not require consent to general jurisdiction. 717 F. App'x 394, 397-98 (5th Cir. 2017). The Fifth Circuit panel stated that it "need not decide [whether Pennsylvania Fire survived International Shoe]" because Pennsylvania Fire could only potentially apply where a "clear statement from the state court constru[es] the [registration] statute to require consent." Id. at 397. Because the panel found that Louisiana law, as evidenced by the text of the registration statute and decisions of the Louisiana Supreme Court, did not expressly require consent to general jurisdiction, it rejected the consent-by-registration argument. Id. at 397-98. A Ninth Circuit panel also considered consent-by-registration of a California statute and rejected the practice in an unpublished opinion. AM Trust v. UBS AG, 681 F. App'x 587, 588-89 (9th Cir. 2017). And the Eleventh Circuit concluded Florida law did not establish consent-by-registration. Waite v. All Acquisition Corp., 901 F.3d 1307, 1318-22 (11th Cir. 2018). 
future. ${ }^{104}$ Federal district courts have also issued a plethora of consentby-registration opinions since the at home trilogy. ${ }^{105}$ In fact, federal district courts remain one of the few places where the plaintiffs' bar has found success advancing consent-by-registration after the trilogy. ${ }^{106} \mathrm{But}$ the judicial fight over consent-by-registration is not limited to federal courthouses and increasingly appears in state courts.

State high courts have decided many consent-by-registration cases in the at home era. The Delaware Supreme Court issued the most significant of these decisions in Genuine Parts Co. v. Cepec. ${ }^{107}$ Cepec concerned a challenge to Delaware's registration statute, which the Delaware Supreme Court previously interpreted as establishing consent to general jurisdiction. ${ }^{108}$ The court rejected its prior interpretation of the statute as an "unacceptably grasping" and "exorbitant" exercise of general jurisdiction because requiring consent to general jurisdiction would subject corporations to suit in many states. ${ }^{109}$ Permitting one state to adopt consent-by-registration would encourage others to adopt similar schemes, "exacting such a disproportionate toll on commerce [that] is

104. The Second Circuit will issue an opinion in an appeal from an order of the Southern District of New York in U.S. Bank National Ass'n v. Bank of America, N.A., No. 15 Civ. 8153 (PGG), 2016 WL 5118298 (S.D.N.Y. Sept. 19, 2016), argued, No. 16-3560 (2d Cir. Nov. 8, 2017).

105. See generally Beck, supra note 84 (collecting recent federal district court decisions on consent-by-registration in all fifty states).

106. See Ritchie Capital Mgmt., Ltd. v. Costco Wholesale Corp., No. 17-1664 (DWF/FLN), 2017 WL 4990520, at *2 \& n.2 (D. Minn. Oct. 30, 2017) (concluding that Costco's registration with the Minnesota Secretary of State established consent to general jurisdiction and rejecting the argument that Tyrrell invalidates consent-by-registration because the Court declined to decide that issue); AK Steel Corp. v. PAC Operating Ltd. P'ship, No. 2:15-CV-09260-CM-GEB, 2017 WL 3314294, at *4 (D. Kan. Aug. 3, 2017) (exercising general jurisdiction based on the defendant's compliance with the Kansas registration statute, which the Kansas Supreme Court interprets as establishing consent to general jurisdiction, because Daimler did not explicitly overturn Pennsylvania Fire); Consol. Infrastructure Grp., Inc. v. USIC, LLC, No. 8:16CV472, 2017 WL 2222917, at *10 (D. Neb. May 18, 2017) (holding that Nebraska's registration statute established consent to general jurisdiction); Ally Bank v. Lenox Fin. Mortg. Corp., No. 16-2387(DSD/DTS), 2017 WL 830391, at *2-3 (D. Minn. Mar. 2, 2017) (affirming general jurisdiction on the basis of Minnesota's registration statute because "appointing an agent for service of process 'gives consent to the jurisdiction of Minnesota courts for any cause of action"” even after Daimler (quoting Knowlton v. Allied Van Lines, Inc., 900 F.2d 1196, 1200 (8th Cir. 1990))). The federal district courts in Pennsylvania, the only state with an explicit consent-by-registration statute, have issued a number of opinions continuing to hold that consent-by-registration satisfies due process even after the at home trilogy. See, e.g., Plumbers' Local Union No. 690 Health Plan v. Apotex Corp., No. 16-665, 2017 WL 3129147, at*11 (E.D. Pa. July 24, 2017) (aggregating opinions from the Eastern District of Pennsylvania continuing to hold that Pennsylvania's explicit consent-by-registration statute comports with due process after the at home trilogy).

107. 137 A.3d 123 (Del. 2016).

108. Id. at 133. The Delaware Supreme Court's prior interpretation of the registration statute permitted consent-by-registration. See Sternberg v. O’Neil, 550 A.2d 1105 (Del. 1988).

109. Cepec, 137 A.3d at 141-43 (citing Daimler AG v. Bauman, 571 U.S. 117, 138-39 (2014)). 
itself constitutionally problematic."110 The Delaware Supreme Court suggested that it could reach a different result if the statute explicitly conditioned registration on consent to general jurisdiction. ${ }^{111}$ But because the Delaware statute did not contain express consent language, the Delaware Supreme Court ultimately held that consent-by-registration violated due process. ${ }^{112}$ The Wisconsin, Missouri, and Illinois Supreme Courts also recently issued consent opinions, and all held that consentby-registration offends due process after the at home trilogy. ${ }^{113}$ These opinions clearly demonstrate a trend away from consent-by-registration in the state courts.

Before Goodyear, Daimler, and Tyrrell, lower courts were divided as to whether a state could require a foreign corporation's consent to general jurisdiction when registering to do business. Lower courts after the at home trilogy increasingly reject implicit consent-by-registration as violating due process under the Supreme Court's newly narrowed standards for general jurisdiction. But few courts have addressed the continued viability of explicit consent-by-registration after the at home trilogy. Having provided background information about general jurisdiction and consent, the analysis that follows argues that a state could expressly require submission to general jurisdiction as a condition

110. Id. at $142-44$.

111. See id. at 142 ("Nothing in the registration statutes explicitly says that a foreign corporation registering thereby consents to the personal jurisdiction of this state. Nothing in the statutes explicitly says that by having to register in order to do any business in this State ... that meant a foreign corporation was waiving any objection to personal jurisdiction for causes of action not arising out of the conduct in Delaware that gave rise to the registration requirement." (quotations omitted)).

112. Id. at 148 .

113. In Segregated Account of Ambac Assurance Corp. v. Countrywide Home Loans, Inc., the Wisconsin Supreme Court considered a challenge to Wisconsin's registration statute, which required designation of an agent for service of process, but did not explicitly claim consent to general jurisdiction as a condition of registration. 898 N.W.2d 70, 76-77 (Wis. 2017). The Wisconsin Supreme Court declined to interpret the statute as incorporating consent-by-registration because the statute itself spoke only to appointing a service agent and because consent-by-registration does not comport with the due process analysis of the at home trilogy. Id.

The Missouri Supreme Court in State ex. rel. Norfolk Southern Railway Co. v. Dolan similarly concluded that an earlier Missouri Supreme Court opinion, which suggested that Missouri's registration statute required consent to general jurisdiction, offended due process. 512 S.W.3d 41, 52-53 (Mo. 2017). The Missouri Supreme Court confirmed its rejection of consent-byregistration again later in the 2017 term. See State ex rel. Bayer Corp. v. Moriarty, 536 S.W.3d 227, 232 (Mo. 2017).

The Illinois Supreme Court also rejected consent-by-registration when interpreting its statute, which also did not contain any express consent language. Aspen Am. Ins. Co. v. Interstate Warehousing, Inc., 90 N.E.3d 440, 447 (IIl. 2017) (holding that "the fact that a foreign corporation registered to do business in Illinois ... in no way suggests that the foreign corporation has consented to general jurisdiction"). 
of doing business in the forum, even after the at home trilogy.

\section{ANALYSIS}

With little chance of obtaining general jurisdiction over a corporate defendant in a forum outside the state of incorporation and principal place of business, plaintiffs' reliance on consent-by-registration will likely persist. ${ }^{114}$ Thus far, the post-trilogy lower court cases mostly involve implicit consent-by-registration. ${ }^{115}$ But few cases address whether a state could explicitly condition registration on consent to general jurisdiction. This part concludes that explicit consent-byregistration comports with due process even after the at home trilogy. After examining the arguments relied on by courts invaliding implicit consent, Section III.A demonstrates the inapplicability of these arguments to explicit consent-by-registration. Section III.B suggests that the Court never overturned its endorsement of consent-by-registration and argues that explicit consent continues to satisfy due process. Permitting an explicit consent-by-registration approach balances the Court's desire to rein in exorbitant exercises of general jurisdiction with the fairness concerns of individual plaintiffs.

\section{A. Attack of the Courts: The Flawed Arguments Against Consent-By- Registration}

Lower courts invoke a common set of argument when invalidating implicit consent-by-registration after the at home trilogy. The arguments typically focus on the significant burdens placed on corporations when subjected to general jurisdiction in many forums. Although reasonably applicable to implicit consent-by-registration, the applicability of these arguments to explicit consent is less apparent. This section examines three arguments frequently forwarded by lower courts and argues that each argument would not apply to explicit consent-by-registration. Section III.A.1 considers the "slippery slope" position-the contention that adoption of consent-by-registration in one state encourages many

114. Rhodes \& Robertson, supra note 6, at 258-60 (arguing that "[i]n the face of a significantly narrowed test for contacts-based general jurisdiction, courts will be faced with new requests for consent-based general jurisdiction" and that "plaintiffs will push for a broad interpretation of what constitutes a defendant's consent to personal jurisdiction"); Sanders, supra note 34, at 1329 (arguing that because "litigants can no longer rely on general jurisdiction based on a power analysis for those corporations not satisfying Daimler's 'at home' test," litigants "must instead turn to consent to assert general jurisdiction").

115. See supra Section II.B.2. 
states to adopt consent-by-registration. Next, Section III.A.2 analyzes the argument that consent-by-registration encourages forum shopping. Finally, Section III.A.3 discusses lower courts exaggeration of the burdens placed on corporate defendants by consent-by-registration. Each argument, although potentially applicable to implicit consent, does not apply to explicit consent-by-registration.

\section{Slippery Slope}

Many courts rejecting implicit consent-by-registration rely on a "slippery slope" argument. The argument posits that: (1) every state has a registration statute; (2) many large corporations register and do business in every state; (3) one state adopting consent-by-registration will encourage others to adopt consent-by-registration; (4) thus, consentby-registration offends due process by subjecting corporations to general jurisdiction in every state. ${ }^{116}$ The cases invoking the slippery slope position demonstrate the argument's inapplicability to explicit consentby-registration.

The Delaware Supreme Court relied on the slippery slope argument in Cepec. The court stated that interpreting its registration statute to require consent would encourage widespread adoption of similar interpretations of registration statutes in other states. ${ }^{117}$ Human experience, the court said, "shows that 'grasping' behavior by one [state], can lead to grasping behavior by everyone, to the collective detriment of the common good."118 Put differently, if Delaware adopts consent-by-registration, then other states will follow their lead and also adopt consent-by-registration. The court cited Daimler in support of this argument. ${ }^{119}$ However, Daimler does not support the court's slippery slope argument.

Daimler referenced "grasping" when discussing a practice which subjects foreign corporations to general jurisdiction in many states other than the state of incorporation and principal place of business. ${ }^{120}$ The

116. E.g., Brown v. Lockheed Martin Corp., 814 F.3d 619, 639-40 (2d Cir. 2016) (finding that an interpretation of Connecticut's registration statute which included consent to general jurisdiction would "creat[e] precisely the result that the Court so roundly rejected in Daimler" because every state has a registration statute and therefore "every corporation would be subject to general jurisdiction in every state in which it registered"); Cepec, 137 A.3d at 125 n.1, 136, 142-44; Ambac, 898 N.W.2d at 81 (quoting Brown, 814 F.3d at 640).

117. Cepec, 137 A.3d at $142-44$.

118. Id. at 143 (citations omitted).

119. Id. at 143 n.111 (citing Daimler AG v. Bauman, 571 U.S. 117, 138 (2014)).

120. Daimler, 571 U.S. at $137-38$. 
Court was not, as Cepec suggests, claiming that states model the jurisdictional practices of other states. Daimler rejected the theory that "doing business" in a state establishes general jurisdiction over corporations. ${ }^{121}$ The Daimler passage cited in Cepec simply states the Court's legal conclusion that if a jurisdictional practice subjects a foreign corporation to general jurisdiction in every state, which the "doing business" approach did, then it is unacceptably grasping. ${ }^{122}$ Daimler did not state that it reached this legal conclusion because evidence suggested that states adopted "doing business" jurisdiction by considering the jurisdictional practices of their neighbor states; rather, the Court simply gave a name to practices which subject large corporations to general jurisdiction in every state: grasping.

Cepec's slippery slope analysis also conflates the existence of registration statutes in every state with the adoption of consent-byregistration in every state. Whereas every state requires registration of foreign corporations and appointment of a service agent, few states explicitly or implicitly claim consent to general jurisdiction as a consequence of registration. ${ }^{123}$ The court provides no evidence that one state amending or reinterpreting its statute to claim consent-byregistration would tempt neighboring states to behave similarly. In fact, for years most states have resisted the temptation placed upon them by the Delaware Supreme Court and have not implemented or reinterpreted their statutes when neighboring states enact consent-by-registration statutes. As the hypothetical below illustrates, simple economics dissuade states without consent-by-registration from modeling a neighbor state's decision to adopt the practice.

Assume, for example, that neighbor States A and B have registration statutes requiring foreign corporations to appoint an agent for service of process. State A amends its statute to explicitly require consent to general jurisdiction as a condition of registration. Basic economic principles dictate that $\mathrm{A}$ and $\mathrm{B}$ compete to attract businesses to their states, ${ }^{124}$ making B unlikely to adopt A's new consent-by-registration approach. ${ }^{125}$ By retaining its service-only statute, B can advertise itself

121. Id. at 139 ("If Daimler's California activities sufficed to allow [general jurisdiction in California] . . . the same global reach would presumably be available in every other state ....").

122. Id. at 136-39 (noting that the plaintiff's theory "appears to subject foreign corporations to general jurisdiction whenever they have an in-state subsidiary or affiliate," a proposition which would subject the defendant to suit in every state).

123. See Monestier, supra note 7, at 1363, 1366-70.

124. See, e.g., Roberta Romano, Law as a Product: Some Pieces of the Incorporation Puzzle, 1 J.L. ECON. \& ORG. 225, 279 (1985) (discussing why firms reincorporate in different states).

125. See Daniel Klerman, Rethinking Personal Jurisdiction, 6 J. Legal ANALysis 245, 259-63 
as a more attractive market for foreign corporations to do business, free from the risk of lawsuits on claims unrelated to activity in B. B's friendly jurisdiction laws could "encourage firms to locate in-state, thus increasing employment and the tax base." 126 The foregoing economic incentives therefore diminish the risk that one state's adoption of consent-by-registration will initiate a slippery slope.

The Delaware Supreme Court's own analysis concedes this point. The court noted that "if the cost of [foreign corporations doing business in Delaware] is that those foreign corporations will be subject to general jurisdiction in Delaware, they rightly may choose not to do so."127 In other words, conditioning access to Delaware's market on jurisdictional consent imposes a high cost on the corporation which exceeds the benefits of registration: the potential that the corporation will be sued on claims unrelated to its forum activity. Therefore, companies would not want to do business in Delaware. ${ }^{128}$ If it is true that consent-byregistration imposes such significant costs on corporations that it discourages registration in the first place, then presumably few state legislatures would adopt consent-by-registration. Thus, the court's conclusion that consent-by-registration would harm the business environment in Delaware undercuts its contention that many states would rush to adopt consent-by-registration if Delaware chose to do so.

Other lower courts also rely on slippery slope arguments. The Wisconsin Supreme Court, for instance, relied on the Second Circuit's reasoning in Brown v. Lockheed Martin Corp. when declining to read consent into the Wisconsin statute. ${ }^{129}$ The Brown court concluded that inferring consent from Connecticut's statute created a result rejected in Daimler because every state has a business registration statute. ${ }^{130}$ As in Cepec, the Second Circuit conflated the existence of registration statutes with the widespread adoption of consent-by-registration. Therefore, the slippery slope argument forwarded by these courts suffers from the same

(2014).

126. Id. at 264

127. Genuine Parts Co. v. Cepec, 137 A.3d 123, 142 (Del. 2016).

128. The U.S. Chamber of Commerce also made this argument in its amicus curiae brief to the Delaware Supreme Court, reasoning that a nationwide system of consent-by-registration "would impose disproportionate costs on Delaware corporations ... while producing no offsetting benefits." Brief of the Chamber of Commerce of the United States of America as Amicus Curiae in Support of Appellant and Reversal at 14, Cepec, 137 A.3d 123 (No. 528, 2015).

129. Segregated Account of Ambac Assurance Corp. v. Countrywide Home Loans, Inc., 898 N.W.2d 70, 81 (Wis. 2017) (quoting Brown, 814 F.3d 619, 640 (2d Cir. 2016)).

130. Brown, 814 F.3d at 640 ("If mere registration and the accompanying appointment of an instate agent... confer[red] general jurisdiction by implicit consent, every corporation would be subject to general jurisdiction in every state in which it registered ...."). 
deficiencies as Cepec's argument.

The cases above demonstrate the flaws in the slippery slope position, as well as the inapplicability of the argument to explicit consent-byregistration. Enacting specific language would put corporations on notice of the consequences of registration and permit calculated decisions about where corporations decide to do business. Additionally, the economic principles currently dissuading states from adopting implicit consent-by-registration apply equally to explicit consent. The Supreme Court could accordingly accept explicit consent-by-registration without causing the "slippery slope" cautioned against by lower courts invalidating implicit consent-by-registration.

\section{Forum Shopping}

A second argument against consent-by-registration is that it increases forum shopping by increasing the number of available general jurisdiction forums. ${ }^{131}$ Professor Tanya Monestier, a proponent of this argument, defines forum shopping as the practice of litigants searching for the most advantageous or beneficial, yet inappropriate, forum in which to file suit. ${ }^{132}$ In Professor Monestier's view, states with consentby-registration become havens for forum shoppers, a phenomenon that will only increase as plaintiffs search for new general jurisdiction

131. See, e.g., Davis v. Quality Carriers, Inc., Nos. 08-4533 (SRC), 08-6262 (SRC), 2009 WL 1291985, at *6 (D.N.J. May 7, 2009) (quoting Landreville v. Joe Brown Co., No. 06-5568, 2008 WL 910009, at*4 (E.D. Pa. Apr. 2, 2008)); Reynolds \& Reynolds Holdings, Inc. v. Data Supplies, Inc., 301 F. Supp. 2d 545, 551 (E.D. Va. 2004); Cepec, 137 A.3d at 146 n.122 (citing several law review articles on forum shopping by plaintiffs in support of the position that consent-by-registration offends due process after Daimler).

The forum shopping argument also appears frequently in amicus briefs filed by advocacy groups in consent-by-registration cases. See Brief of the Chamber of Commerce of the United States of America as Amicus Curiae in Support of Appellant and Reversal, supra note 128, at 15 ("Permitting general jurisdiction based on compelled consent ... would destroy that predictability and dramatically increase Delaware corporations' legal costs. Plaintiffs seeking to bring lawsuits against Delaware companies would be able to engage in forum shopping, choosing where to bring suit not on the basis of where the underlying events occurred or where the defendant was located but on which jurisdiction they perceived as friendliest to plaintiffs."); Brief of Coalition for Litigation Justice, Inc., and American Insurance Ass'n as Amici Curiae in Support of Appellant and in Support of Reversal of the Decision of the Trial Court at 7-14, Cepec, 137 A.3d 123 (No. 528, 2015) (advancing the consent-by-registration forum shopping argument in the context of asbestos personal injury and other mass tort cases); Amicus Curiae Brief of the Coalition for Litigation Justice in Support of Countrywide Home Loans' Appeal of the Court of Appeals Exercise of General Jurisdiction at 3-5, Ambac, 898 N.W.2d 70 (No. 2015AP1493); Amicus Brief of Wisconsin Manufacturers \& Commerce Ass'n \& the Chamber of Commerce of the United States of America at 11-12, Ambac, 898 N.W.2d 70 (No. 2015AP1493).

132. Monestier, supra note 7, at 1409-10. 
theories after the at home trilogy. ${ }^{133}$ But even if consent-by-registration increases forum shopping, that does not explain why courts should reject consent-by-registration.

Courts also overstate the consequences of forum shopping. ${ }^{134}$ In many respects, the American judicial system values and even encourages shopping. ${ }^{135}$ Federal diversity jurisdiction, for instance, "permits Congress to authorize forum shopping between state and federal court precisely to enable out-of-state parties to forum shop away from state courts." 136 Venue and jurisdictional statutes are other ways in which the American judicial system permits some discretion in plaintiffs' choice of forum. ${ }^{137}$ Despite the many ways in which forum shopping is ingrained in the legal system, the legal community denounces the practice. ${ }^{138}$ The presumption against forum shopping raises significant concerns for how courts evaluate the burdens imposed on corporations by consent-byregistration.

For example, the Delaware Supreme Court's description of the negative consequences of forum shopping in Cepec amounts to a single footnote citing five law review articles. ${ }^{139}$ Three of the articles were

133. Id. at 1410-12 (arguing that plaintiffs before Goodyear did not need to rely on consent-byregistration given the availability of the broader "doing business" minimum contacts analysis from International Shoe).

134. See Pamela K. Bookman, The Unsung Virtues of Global Forum Shopping, 92 NotRE DAME L. REV. 579, 582-83 (2016) ("[C]ritics rarely offer specific explanations as to why global forum shopping should be so widely condemned.").

135. Debra Lyn Bassett, The Forum Game, 84 N.C. L. REV. 333, 352 (2006) ("If forum shopping were indeed a devious, illegitimate, and unfair practice, one would expect the law to circumscribe the available forum options and would expect the Supreme Court to criticize the forum shopping practice. But this is not the case. The law regularly authorizes a choice between two or more legitimate forums, and the Supreme Court generally has recognized the validity of forum shopping, criticizing the practice only in one very narrow context."); Bookman, supra note 134, at 598-99 (noting that Erie "did nothing to address the incentives for forum shopping ... between different U.S. states" and that "[o]pportunities for [this] kind[] of forum shopping flourish[es] under Erie").

136. Bookman, supra note 134, at 599.

137. Mary Garvey Algero, In Defense of Forum Shopping: A Realistic Look at Selecting a Venue, 78 NeB. L. REV. 79, 82-83 (1999).

138. See Bassett, supra note 135, at 336-37 ("Despite the frequent availability of a choice in selecting a forum due to the existence of more than one lawfully authorized forum, 'forum shopping' is undeniably a pejorative term.... [A] United States Supreme Court Justice has denounced forum shopping as 'evil.' Congressional efforts to limit forum shopping ... portray[] the practice as abusive, devious, and unethical.... Critics ... charge manipulation, wrongdoing, and abuse by lawyers (invariably plaintiffs' lawyers) to obtain a forum and substantive law to which they are not entitled. Indeed, critics charge, so egregious and abusive is this behavior that sanctions should be mandated."); Bookman, supra note 134, at 582 (discussing the "widely reviled" nature of forum shopping, and noting "[t]he Supreme Court speaks of the practice with great disdain, vowing to protect U.S. courts from it").

139. Genuine Parts Co. v. Cepec, 137 A.3d 123, 146 n.122 (Del. 2016). The court cited 
published before the at home trilogy, and accordingly do not account for new restrictions on general jurisdiction which rein in forum shopping. ${ }^{140}$ The first article is about transnational forum shopping, which the article argues places a litigation tax on large multinational corporations. ${ }^{141}$ Legal scholars question the empirical support for the litigation tax argument, ${ }^{142}$ and note that the Supreme Court's decisions in other areas already significantly reduce the risk of transnational forum shopping. ${ }^{143}$ The second and third articles reference mass tort forum shopping and resolving mass tort claims in bankruptcy courts. ${ }^{144}$ Neither author quantifies the occurrence of forum shopping. ${ }^{145}$ Nor does either author account for recent opinions curbing mass tort forum shopping. ${ }^{146}$ Only

primarily Alan O. Sykes, Transnational Forum Shopping as a Trade and Investment Issue, $37 \mathrm{~J}$. Legal Stud. 339, 339 (2008), Douglas G. Smith, Resolution of Mass Tort Claims in the Bankruptcy System, 41 U.C. DAVIS L. REV. 1613, 1621 (2008), and Lester Brickman, Lawyers' Ethics and Fiduciary Obligation in the Brave New World of Aggregative Litigation, 26 WM. \& MARY ENVTL. L. \& POL'Y REV. 243, 258 (2001); the court cited secondarily Matthew D. Cain \& Steven Davidoff Solomon, A Great Game: The Dynamics of State Competition and Litigation, 100 IOWA L. REV. 465, 468, 477 (2015) and Minor Myers, Fixing Multi-Forum Shareholder Litigation, 2014 U. ILL. L. REV. 467, 479-99 (2014).

140. Brickman, supra note 139; Smith, supra note 139; Sykes, supra note 139.

141. Sykes, supra note 139 , at 339.

142. See Arthur R. Miller, McIntyre In Context: A Very Personal Perspective, 63 S.C. L. REv. 465,469 (2012) (condemning the vilification of the plaintiffs' bar and discussing the "[b]ogus statistics" supporting the litigation tax argument).

143. See Bookman, supra note 134, at 600 ("[T]he Court has strengthened the barriers against such suits by fortifying the presumption against extraterritorial application of federal statutes, the forum non conveniens doctrine, and a restrictive view of personal jurisdiction. There is a judicial crusade against global forum shopping."); Christopher A. Whytock, The Evolving Forum Shopping System, 96 CORNELL L. REV. 481, 483-84 (2011) (conducting an empirical analysis of transnational forum shopping and concluding that "the forum shopping system has evolved and no longer encourages plaintiffs to file transnational suits in U.S. courts" and that "there actually has been less - not more - transnational forum shopping into U.S. courts over the last two decades").

144. Brickman, supra note 139, at 258 (contending that "forum shopping has become a prominent factor in accounting for increased class action filings"); Smith, supra note 139, at 1621.

145. Smith does not argue that forum shopping, on the aggregate, occurs more frequently than in other historical periods. Instead, Smith's argument is that mass tort cases concentrate in a few plaintiff-friendly districts. Smith, supra note 139, at 1621 (arguing that claims "have gravitated toward certain jurisdictions that plaintiffs believe are more favorable" and therefore the "bulk of the litigation has occurred in a handful of jurisdictions").

146. For example, the Court's decision last term in Bristol-Myers Squibb Co. v. Superior Court, 137 S. Ct. 1773 (2017), significantly narrowed the scope of specific jurisdiction. Many legal commentators argue that the decision is a death sentence for mass tort forum shopping. See Kara Kapke, High Court Limits Litigation Forum Shopping, NAT'L L. REV. (June 20, 2017), https://www.natlawreview.com/article/high-court-limits-litigation-forum-shopping [https://perma.cc /P76X-QNLB] ("[The decision] firmly curtail[s] the ability of out-of-state residents to forum shop for a favorable jurisdiction in mass tort litigation," thus "slamming the door to mass tort forum shopping for out-of-state residents."); Richard Levick, The Game Changes: Is Bristol-Myers Squibb The End Of An Era?, ForBeS (July 11, 2017, 2:21 PM), https://www.forbes.com/sites/richard levick/2017/07/11/the-game-changes-is-bristol-myers-squibb-the-end-of-an-era/\#6c9819582e83 [https://perma.cc/X7MT-GVDE] ("[Bristol-Myers Squibb] fundamentally changes the rules 
the final two articles in the Cepec footnote attempt to empirically evaluate the occurrence of forum shopping. ${ }^{147}$ Yet neither article blames general jurisdiction or consent-by-registration for increases in forum shopping. The Delaware Supreme Court cited these five articles to support its conclusion that courts should reject jurisdictional practices which encourage forum shopping, but none of these articles make a legitimate case against forum shopping.

Presumably, fears about increased litigation costs supply the bulk of courts' concerns with forum shopping. Yet empirical data does not support the contention that personal jurisdiction contributes to higher litigation costs:

While it is intuitive to assume that it is significantly more expensive ... to litigate out-of-state, this assumption is not well-founded. There are no empirical studies documenting increased costs for out-of-state litigants, and conversations with lawyers suggest that ... distance has little or no impact on litigation costs.... When asked to quantify the cost difference between litigating in state and out-of-state, most lawyers ... answered "less than two percent."

Electronic communication and significant reductions in the cost of travel also decrease the effect of forum on litigation costs. ${ }^{149}$ Altogether, "the forum is unlikely to significantly affect overall litigation costs;" and even when it does, "personal jurisdiction rules may be relatively powerless to reduce overall costs."

governing where corporate defendants can be sued and effectively limits the forum-shopping that has driven 'mass action' lawsuits in the past."); Richard Dean \& Michael Ruttinger, How BristolMyers Squibb May Transform Class Actions, LAw360 (October 11, 2017, 10:39 AM), https://www.law360.com/articles/973105/how-bristol-myers-squibb-may-transform-class-actions [https://perma.cc/Z6SA-ZPAR] (noting "high-profile dismissals from several jurisdictions" in the wake of Bristol-Myers Squibb); David R. Fine, In a Series of Personal-Jurisdiction Cases, the Supreme Court Gives Businesses Tools Against Forum Shopping, K\&L GATES (June 21, 2017), http://www.klgates.com/in-a-series-of-personal-jurisdiction-cases-the-supreme-court-gives-business es-tools-against-forum-shopping-06-21-2017/ [https://perma.cc/248Z-FJYA] ("[T]he string of personal-jurisdiction cases from the Supreme Court might well provide ammunition to defend against forum shopping.").

147. Cain \& Solomon, supra note 139, at 477; Myers, supra note 139, at 479-99.

148. Klerman, supra note 125 , at 250.

149. Id. at 250-51. Klerman argues that because almost all documentation in lawsuits today is stored electronically, "physical proximity to files is largely irrelevant." Id. at 250. Additionally, Klerman points out that "since most communication these days is done by phone, email, or conference call, whether the lawyer and the client are in the same city is unlikely to significantly affect total litigation costs. In addition, the cost of travel, especially air travel, has dropped significantly in recent decades, while the cost of lawyer's time has increased, so the cost of travel is generally insignificant" to overall litigation costs. Id. at 250-51.

150. Id. at $253-54$. 
Courts should not use forum shopping as a justification for invaliding consent-by-registration. And at the very least, courts should account for recent efforts to rein in forum shopping in other areas when deciding consent cases. And even if consent-by-registration increases forum shopping, courts should articulate why forum shopping should be avoided in the first place. Consequently, the Supreme Court should not rely on forum shopping concerns when evaluating whether consent-byregistration comports with due process.

\section{Corporate Burdens}

Courts often argue that consent-by-registration imposes significant financial and practical burdens on corporate defendants. However, corporate burdens do not warrant the rejection of explicit consent-byregistration for three reasons. First, courts ignore the various procedural mechanisms that diminish any expense and inconvenience to corporate defendants caused by consent-by-registration. Second, courts should balance corporate burdens with fairness concerns of individual plaintiffs. And third, explicit consent-by-registration significantly reduces corporate burdens.

First, corporate defendants possess a vast arsenal of pre-trial procedural weapons capable of mitigating the burdens placed on them by consent-by-registration. ${ }^{151}$ Venue transfer protects against any general jurisdiction litigation burdens by permitting the defendant to second guess the plaintiff's forum choice, even if the forum had personal jurisdiction. ${ }^{152}$ One study examining three million federal cases over a thirteen year period found that venue transfers reduced the plaintiff win rate "from $58 \%$ in cases in which there is no transfer to $29 \%$ in transferred cases." 153 Transfer thus benefits corporate defendants with resources exceeding those of their individual plaintiff counterparts. ${ }^{154}$

151. Daimler AG v. Bauman, 571 U.S. 117, 156 (2014) (Sotomayor, J., concurring) (identifying venue and forum non conveniens as mitigating "any resulting unfairness to large corporate defendants"); Borchers, supra note 29, at 138 ("[V]enue transfer and the common law doctrine of forum non conveniens give the defendant some opportunity to influence the choice of forum even if the plaintiff succeeds in establishing jurisdiction.").

152. Borchers, supra note 29, at 138.

153. Kevin M. Clermont \& Theodore Eisenberg, Exorcising the Evil of Forum-Shopping, 80 CORNELL L. REV. 1507, 1507 (1995). The decline likely occurs because transfers increase plaintiffs' litigation costs, forcing them to accept lesser settlements, settle cases earlier, or drop the suit entirely. See id. at 1514-15.

154. See Roger Michalski, Transferred Justice: An Empirical Account of Federal Transfers in the Wake of Atlantic Marine, 53 Hous. L. REV. 1289, 1289-90 (2016) ("[M]any transfers benefit corporate defendants and adversely affect individuals whose cases are transferred far away from 
Therefore, although jurisdiction initially favors the plaintiff, transfer "shift[s] the balance of litigation and bargaining powers" back in defendant's favor, thereby "protect[ing] against inconvenient and unwelcom[e] forums." "155 One could argue that transfers burden defendants by increasing litigation expenses. However, most transfer motions go uncontested and only marginally affect costs, and legal commentators may often exaggerate transfer expenses. ${ }^{156}$ In reality, venue transfers effectively balance out the burdens placed on corporate defendants subjected to suit in an inconvenient forum away from home. ${ }^{157}$

The doctrine of forum non conveniens also provides particular protection against unfairness to multinational corporations, a harm cautioned against in Daimler and relied on by courts invalidating consent-by-registration. ${ }^{158}$ However, forum non conveniens already reduces that burden by allowing federal district courts to dismiss a case when a more convenient forum exists in a foreign country. ${ }^{159}$ Even before the at home trilogy's narrowing of general jurisdiction, federal district courts used this doctrine aggressively to dismiss transnational litigation. ${ }^{160}$ Despite the Court's concern for transnational forum shopping absent new restrictions on general jurisdiction, forum non conveniens already equips courts with the flexibility necessary to "deter international forum shopping while preserving the efficiencies of liberal jurisdictional rules for domestic suits." 161 Because forum non conveniens

their chosen forum.... [thus] tilt[ing] the litigation playing field in favor of institutional actors at the expense of individuals.").

155. Id. at 1314 .

156. Clermont \& Eisenberg, supra note 153, at 1529-30 (examining data on transfer motions in federal court and finding that few transfers are contested, and few receive hearings in court).

157. When forum shopping plaintiffs select an unjust forum, "courts are transferring cases to more just courts, so that the decrease in the win rate reflects the fact that courts are stripping plaintiffs of unjust forum advantages." Id. at 1507.

158. Daimler AG v. Bauman, 571 U.S. 117 (2014).

159. See 14D Charles Alan Wright et al., Federal Practice \& Procedure $\S 3828$ (4th ed. 2013) (describing district courts' ability to dismiss or stay a case under the forum non conveniens doctrine if the only "superior alternative forum" is a court in another country).

160. Whytock, supra note 143, at 529 (examining data claiming that there is an explosion of transnational litigation in the U.S. and finding that "the current system is unlikely to encourage transnational forum shopping into U.S. courts" and that "U.S. district court judges aggressively use the forum non conveniens doctrine to dismiss transnational litigation").

161. Daniel J. Dorward, Comment, The Forum Non Conveniens Doctrine and the Judicial Protection of Multinational Corporations from Forum Shopping Plaintiffs, 19 U. PA. J. INT'L ECON. L. 141, 168 (1998). Dorward also discusses the particular problems imposed by courts issuing due process restrictions on personal jurisdiction as compared to courts continuing to rely on forum non conveniens as a solution to transnational forum shopping. See id. at 167-68 (cautioning against due process personal jurisdiction restrictions because those changes "would affect domestic as well as 
moderates the occurrence of transnational shopping, courts should not give this much weight when considering the effects of consent-byregistration.

Second, the Supreme Court should not view arguments about fairness or burdens inflicted on corporations in a vacuum. General jurisdiction is a single procedural cog in a larger civil litigation machine. It is therefore illogical to decry one aspect of the civil system as egregiously unfair to corporate defendants without also considering the fairness of the system as a whole. Even if permitting consent-byregistration tips the scales slightly towards plaintiffs, "other aspects of [the] system are distinctly pro-defendant and tend to counterbalance the pro-plaintiff attributes." 162 The litany of pro-defendant financial and procedural tools available to large corporations therefore offset whatever consequences emerge from widespread adoption of consent-byregistration. ${ }^{163}$ And given the Court's continuing restriction of specific jurisdiction, ${ }^{164}$ a marginal expansion of the scope of general jurisdiction would merely offset recent gains made by defendants and restore the jurisdictional balance upset by the at home trilogy.

Courts should therefore consider the types of corporations even capable of subjecting themselves to suit in every state. Every negative consequence of consent-by-registration described in this comment emanates from the same exaggerated fear: that some corporations will be subject to general jurisdiction in all or nearly all fifty states. ${ }^{165}$ The only

international litigation" and "[t]he current [personal jurisdiction] rules may be efficient for domestic litigation, for which forum shopping is less of a concern").

162. Note, Forum Shopping Reconsidered, 103 HARV. L. ReV. 1677, 1688-89 (1990) (arguing that although forum shopping benefits plaintiffs, it would be a mistake to see that as a "deviation from some baseline of neutrality" because other pro-defendant aspects of the system balance out any unfairness).

163. Id. at 1679-80 (listing removal to federal court, challenges to subject matter jurisdiction and venue, forum non conveniens, challenging manufactured diversity of citizenship, juror challenges, suing for declaratory judgment, and forum selection clauses as examples of defendants engaging in forum shopping).

164. Leslie A. Brueckner \& Andre M. Mura, The Supreme Court Puts Personal Jurisdiction on Trial, LAW 360 (May 22, 2017, 11:41 AM), https://www.law360.com/articles/926482/ print?section=appellate. Other aspects of the Court's recent civil procedure cases additionally tip civil litigation scales in the defendant's favor. See, e.g., Rhodes \& Robertson, supra note 6, at 210 (highlighting more lenient summary judgment standards for defendants, enhanced expert witness evidentiary standards, and heightened pleading standards as "markedly influenc[ing] the course of civil litigation").

165. The slippery slope argument, discussed in Section III.A.1, posits that states will follow each other's lead in adopting consent-by-registration, and eventually every state will adopt the practice to the detriment of commerce. The forum shopping argument also relies on this logic, and as discussed in Section III.A.2, the defense bar argues that the ills of forum shopping occur when the plaintiff has a choice of many forums, allowing the plaintiff to pick a highly inconvenient one. 
businesses capable of consenting to general jurisdiction in all fifty states are large national and multinational corporations registered and doing business in all fifty states. ${ }^{166}$ The burdens imagined by courts rejecting consent-by-registration, therefore, only apply to the world's largest corporations, and it is "[p]recisely this type of defendant [who] is best equipped to protect itself against future legal action in an inconvenient forum." 167

Finally, explicit consent resolves corporate litigation burdens potentially resulting from consent-by-registration. The reason registration could burden foreign corporations in the first place is because state statutes do not mention personal jurisdiction and speak only to appointment of an agent for service of process. ${ }^{168}$ Although foreign corporations lack notice of the consequences of registration under an implicit consent scheme, the situation is different where the text of a registration statute explicitly notifies applicants of the consequences of registration, allowing them to make voluntary choices as to whether they wish to accept the risk of registering and subjecting themselves to general jurisdiction. ${ }^{169}$ When dealing with explicit consent, it is reasonable to charge registering businesses with knowledge of the consequences of compliance because of the sophistication of the entities involved:

166. Genuine Parts Co. v. Cepec, 137 A.3d 123, 143 (Del. 2016) (noting that Delaware corporations "must operate in all fifty states and worldwide to compete").

167. Note, Forum Shopping Reconsidered, supra note 162, at 1691-92.

168. See Brown v. Lockheed Martin Corp., 814 F.3d 619, 637 (2d Cir. 2016) (concluding that Connecticut's registration statute did not provide a permissible means of establishing the defendant corporation's consent to general jurisdiction because it gave "no notice to [the] corporation registering to do business in the state that the registration might have the sweeping effect" of claiming consent to general jurisdiction); Cepec, 137 A.3d at 138-42 (the Delaware Supreme Court could not read consent to general jurisdiction into the registration statute because "[n]otably absent [from a prior Delaware Supreme Court decision] was any reference to explicit statutory language ... that suggested that by registering under $\S 371$ and designating an in-state agent for service of process, the foreign corporation was thereby consenting to the general personal jurisdiction of Delaware" and because the registration statute, unlike the Delaware long-arm statute which explicitly references personal jurisdiction, contained nothing that "explicitly says that a foreign corporation registering thereby consents to the personal jurisdiction of this state"); State ex. rel. Norfolk S. Ry. Co. v. Dolan, 512 S.W.3d 41, 52 (Mo. 2017) (leaving open the possibility of a statute explicitly conditioning consent to general jurisdiction on doing business as a foreign corporation in Missouri, noting that "this Court finds there is no need to determine whether Missouri's registration statutes constitutionally could condition doing business in Missouri on consent to general jurisdiction.... The plain language of Missouri's registration statutes does not mention consent ... nor does it purport to provide an independent basis for jurisdiction over foreign corporations that register in Missouri”); Segregated Account of Ambac Assurance Corp. v. Countrywide Home Loans, Inc., 898 N.W.2d 70, 77 (Wis. 2017) (stating that the Wisconsin statute refers only to service of process, not personal jurisdiction, and rejecting an implicit consent argument similar to the one raised in Cepec).

169. Harrison, supra note 2, at 540-41. 
[C]orporations are more likely to be familiar with the laws of a state ... than an individual defendant.... Some corporations are highly sophisticated companies with legions of ... lawyers at their disposal for the express purpose of investigating every possible legal risk those companies face. Obviously, for one of those companies it would be much easier to anticipate where it might be subject to jurisdiction when deciding where ... to conduct business than it would be for an ordinary person....

Because explicit consent puts these sophisticated private entities on notice of the jurisdictional consequences of registration, it allows them to choose whether they wish to accept these consequences. ${ }^{171}$ Therefore, registration statutes explicitly conditioning permission to do business in a state on the corporation's consent to general jurisdiction in the courts of that state mitigates any burden imposed on the registering corporation.

In conclusion, explicit consent-by-registration should survive an attack premised on the arguments most commonly used to invalidate implicit consent-by-registration after the at home trilogy. The "slippery slope" argument fails because it assumes that every state will rush to adopt consent-by-registration, despite the existence of economic incentives to the contrary. The forum shopping argument similarly fails as it is typically invoked without empirical evidence or an explanation of the extent to which personal jurisdiction contributes to forum shopping. And lastly, courts ignore the litany of procedural tools which reduce unfairness and inconvenience to corporations in defending lawsuits away from home. When the Supreme Court resolves the issue of consent-byregistration, it should avoid repeating these mistakes because how the Court goes about calculating the defendant's litigation burdens is the essence of the due process inquiry. If consent-by-registration does not really burden corporate defendants, then the practice may actually comport with due process under the at home test for general jurisdiction. The next section advances that position.

\section{B. Plaintiffs' New Hope: Explicit Consent-By-Registration}

Lower state and federal courts face a jurisdictional paradox when confronted with the issue of consent-by-registration. Although the

170. Cody J. Jacobs, If Corporations Are People, Why Can't they Play Tag?, 46 N.M. L. REv. 1, 22 (2016) (footnotes omitted).

171. See id. at $22 \mathrm{n} .131$ (arguing that "a disproportionate number of major corporate CEOsand probably other officers_-are lawyers themselves" (citing Michael Simkovic \& Frank McIntyre, The Economic Value of a Law Degree 7 n.8 (HLS Program on the Legal Profession, Research Paper No. 2013-6), http://papers.ssrn.com/sol3/papers.cfm?abstract_id=2250585)). 
Court's recent cases limit general jurisdiction over corporations to the state of incorporation and principal place of business, the Court also never expressly overturned consent-by-registration cases which would permit general jurisdiction in places other than the state of incorporation and principal place of business. This section offers a suggestion to resolve that paradox by arguing that consent-by-registration continues to satisfy the constitutional due process requirements of personal jurisdiction. Rather than inconsistent with the at home test, consent-byregistration fits squarely within the Court's reasoning in adopting the test for general jurisdiction. This section first argues that the Supreme Court never overturned Pennsylvania Fire, and the case therefore remains a viable basis for affirming states' ability to adopt consent-by-registration. Second, this section contends that consent-by-registration actively promotes the policy goals of the at home trilogy of promoting predictably simple rules for general jurisdiction. Because the Court resolved the issue one-hundred years ago, and because reaffirming the issue will promote the jurisdictional goals fashioned in the trilogy, the Court should confirm that consent-by-registration satisfies due process even after the at home trilogy.

\section{The At Home Trilogy Did Not Overturn Pennsylvania Fire}

The Supreme Court never overturned Pennsylvania Fire and continues to endorse consent-by-registration after the at home trilogy. Pennsylvania Fire held that a state's decision to condition access to its market on a foreign corporation's consent to general jurisdiction comports with due process. ${ }^{172}$ The Court affirmed Pennsylvania Fire's holding four years later. ${ }^{173}$ And a few years before International Shoe, the Court again affirmed Pennsylvania Fire's holding. ${ }^{174}$ Clearly then, the Court accepted the theory of consent-by-registration at least up until International Shoe, and the only question is whether its subsequent decisions overruled Pennsylvania Fire. ${ }^{175}$ This section argues that the

172. Pa. Fire Ins. Co. of Phila. v. Gold Issue Mining \& Milling Co., 243 U.S. 93, 95-96 (1917).

173. Robert Mitchell Furniture Co. v. Selden Breck Const. Co., 257 U.S. 213, 215-16 (1921) (denying personal jurisdiction in Ohio because that state's registration statute did not expressly require consent to general jurisdiction and the Ohio Supreme Court had not interpreted the statute as requiring consent to general jurisdiction).

174. Neirbo Co. v. Bethlehem Shipbuilding Corp., 308 U.S. 165, 175 (1939) (citing Pa. Fire's holding in concluding that a corporation waived its ability to contest venue by complying with a New York registered agent statute, which the New York Court of Appeals had interpreted as consent to suit in New York).

175. See Forest Labs., Inc. v. Amneal Pharm. LLC, No. 14-508-LPS, 2015 WL 880599, at *6 (D. Del. Feb. 26, 2015) (When confronted with the question of whether "one of the ways in 
Court did not overturn Pennsylvania Fire in International Shoe or any of its other subsequent personal jurisdiction cases. This section also responds to arguments that the Court in International Shoe and its progeny implicitly overturned Pennsylvania Fire. Because the Court on numerous occasions declined to explicitly overturn Pennsylvania Fire when it otherwise could have done so, consent-by-registration remains a viable means of obtaining general jurisdiction over corporations.

The Court's personal jurisdiction precedent after International Shoe and before the at home trilogy did not overturn Pennsylvania Fire's approval of consent-by-registration. Yet many courts contend otherwise in cases rejecting consent-by-registration, arguing that International Shoe implicitly eliminated consent-by-registration. ${ }^{176}$ The Court decided Pennsylvania Fire, they argue, in an era where states could only exercise judicial power over entities "physically present" within their territory, and thus states extracted consent to jurisdiction out of a necessity to hold foreign corporations amenable to suit. ${ }^{177}$ That is, the foreign corporation's registration made them "physically present" in the state and thus the state's courts could exercise personal jurisdiction over them. ${ }^{178}$ International Shoe thus "dispensed with [this] 'purely fictional' notion[] of implied consent and presence-by-agent, and redirected personal jurisdiction doctrine away from the territorial approach."179 These courts additionally argue that the Court in Shaffer v. Heitner ${ }^{180}$ made known its intent to overturn its pre-International Shoe personal jurisdiction cases, and thus the Court implicitly overturned Pennsylvania Fire. ${ }^{181}$ Because the Shaffer Court concluded that "all assertions of statecourt jurisdiction must be evaluated according to the standards set forth in International Shoe and its progeny,"182 these courts evaluate consentby-registration under a post-International Shoe analysis and conclude that Pennsylvania Fire no longer applies. ${ }^{183}$ For these reasons, many courts conclude that Pennsylvania Fire has been implicitly overturned

\footnotetext{
which... consent can be manifested is when a corporation complies with a state registration statute," the court concluded that "prior to International Shoe, the Supreme Court's answer to [that] question was 'yes."').

176. See, e.g., Genuine Parts Co. v. Cepec, 137 A.3d 123, 138 n.78, 142 n.103 (Del. 2016).

177. See Brown v. Lockheed Martin, 814 F.3d 619, 631-33 (2d Cir. 2016).

178. See id.

179. Segregated Account of Ambac Assurance Corp. v. Countrywide Home Loans, Inc., 898 N.W.2d 70, 75 (Wis. 2017) (quoting Burnham v. Superior Court, 495 U.S. 604, 618 (1990)).

180. 433 U.S. 186 (1977).

181. See, e.g., Cepec, 137 A.3d at 142 n.103 (citing Shaffer, 433 U.S. 186 at 212 \& n.39).

182. 433 U.S. at 212.

183. See Cepec, 137 A.3d at 142 n.103.
} 
and that consent-by-registration no longer comports with due process.

International Shoe's language, however, refutes the proposition that the Court overturned Pennsylvania Fire and consent-by-registration. The Court addressed only cases of fictional consent, where a state took the presence of a foreign corporation's employee in the state as the corporation's "physical presence" and thus submission to jurisdiction. ${ }^{184}$ The Court did not mention Pennsylvania Fire in International Shoe, and the Court did not expressly overturn its earlier approval of consent-byregistration in subsequent cases. ${ }^{185}$ The lack of an express statement from the Court overturning Pennsylvania Fire should bind lower courts because only the Court may overturn its own decisions. ${ }^{186}$ The Court's personal jurisdiction cases after International Shoe additionally refute the position that the Court no longer recognizes cases of consent. ${ }^{187}$ Indeed, "[i]n the almost 100 years since the Supreme Court decided Pennsylvania Fire, it has had ample opportunity to reconsider its holding. Yet each time the issue arose, the Supreme Court reaffirmed that registration statutes... could confer jurisdiction through consent...."188 International Shoe itself can therefore not be read as overturning consent-by-registration.

Moreover, Shaffer did not overturn Pennsylvania Fire. Shaffer involved quasi in rem jurisdiction. ${ }^{189}$ As the Court later clarified, it intended to limit its statement in Shaffer that "all assertions of state-court jurisdiction" pass through International Shoe's minimum contacts

184. See Forest Labs., Inc. v. Amneal Pharm. LLC, No. 14-508-LPS, 2015 WL 880599, at *45 (D. Del. Feb. 26, 2015) (citing International Shoe Co. v. Washington, 326 U.S. 310, 318 (1945)) (explaining that the Court's discussion of consent referred to cases where courts took the presence of a corporation's agent in the state as consent to suit).

185. See Acorda Therapeutics Inc. v. Mylan Pharm. Inc., 817 F.3d 755, 768 (Fed. Cir. 2016) (O’Malley, J., concurring); In re Syngenta AG MIR 162 Corn Litig., No. 14-md-2591-JWL, 2016 WL 1047996, at*2 (D. Kan. Mar. 11, 2016); Forest Labs., 2015 WL 880599, at*7-10.

186. Rodriguez De Quijas v. Shearson/Am. Express, Inc., 490 U.S. 477, 484 (1989) ("If a precedent of this Court has direct application in a case, yet appears to rest on reasons rejected in some other line of decisions, the Court of Appeals should follow the case which directly controls, leaving to this Court the prerogative of overruling its own decisions.").

187. See generally Syngenta, $2016 \mathrm{WL} 1047996$, at *2 (discussing a line of cases postInternational Shoe affirming the Pennsylvania Fire line of cases). In Olberding v. Illinois Central R. Co., 346 U.S. 338, 341-42 (1953), the Court cited Neirbo approvingly in affirming venue in Kentucky through the defendant's compliance with a business registration statute. And in Insurance Corp. of Ireland v. Compagnie des Bauxites de Guinee, 456 U.S. 694, 704 (1982), the Court affirmed the ability of the defendant to waive objection to personal jurisdiction and noted it had previously upheld certain state procedures which take the "voluntary use of certain state procedures" as "constructive consent to the personal jurisdiction of the state court."

188. Acorda, 817 F.3d 755, 768 (Fed. Cir. 2016) (O’Malley, J., concurring).

189. Shaffer v. Heitner, 433 U.S. 186, 208 (1977). 
analysis only to assertions of quasi in rem jurisdiction. ${ }^{190}$ Shaffer did not apply its holding to cases of consent-by-registration, nor did it mention Pennsylvania Fire. ${ }^{191}$ Thus, the lack of explicit reference to Pennsylvania Fire again refutes the conclusion that Shaffer implicitly overturned consent-by-registration.

Some courts maintain that even if International Shoe did not overturn Pennsylvania Fire, its subsequent cases, especially the at home trilogy, did. ${ }^{192}$ The at home cases, however, do not discuss, criticize, or even mention the Pennsylvania Fire line of consent-by-registration cases. In fact, the sole mention of consent in these cases suggests the continued viability of the practice. In Goodyear, the Court uses "consent" one time when referencing Perkins as the "textbook case of general jurisdiction appropriately exercised over a foreign corporation that has not consented to suit in the forum." 193 The Court in establishing the at home test thus exempted its application to cases where a corporation consented to suit in the forum. The Court cited that statement from its Goodyear decision again in Daimler, thus further distinguishing the application of the at home test from cases of consent, and "undermining any argument that the Court intended to speak to the issue of consent." 194 Consequently, not even the restrictive at home test adopted in Goodyear, Daimler, and Tyrrell overturns the constitutionality of consent-by-registration.

190. See Burnham v. Superior Court, 495 U.S. 604, 620-21 (1990) (plurality opinion) (interpreting Shaffer as saying "not that all bases for the assertion of in personam jurisdiction... must be treated alike and subjected to the 'minimum contacts' analysis of International Shoe; but rather that quasi in rem jurisdiction ... and in personam jurisdiction, are really one and the same and must be treated alike-leading to the conclusion that quasi in rem jurisdiction... must satisfy the litigation-relatedness requirement of International Shoe"); Forest Labs., 2015 WL 880599, at *7.

191. See Acorda Therapeutics, Inc. v. Mylan Pharm. Inc., 78 F. Supp. 3d 572, 589 n.13 (D. Del. 2015), rev'd 817 F.3d 755 (Fed. Cir. 2016) (the court declined to read "the Supreme Court's seemingly broad statement in Shaffer ... to apply to situations in which a defendant has consented to jurisdiction, or has otherwise waived the requirement of personal jurisdiction" (citations omitted)).

192. See, e.g., Brown v. Lockheed Martin, 814 F.3d 619, 637-39 (2d Cir. 2016). In Brown, the Second Circuit concluded that given the move away from International Shoe's minimum contacts analysis and towards the at home test for general jurisdiction, "federal due process rights likely constrain an interpretation that transforms a run-of-the-mill registration and appointment statute into a corporate 'consent' ... to the exercise of general jurisdiction by state courts." Id. at 637 . The court considered Pennsylvania Fire and concluded that it "is now simply too much at odds with the [at home test] to govern" and that the "Court's analysis in recent decades ... forecloses such an easy use of Pennsylvania Fire to establish general jurisdiction over a corporation based solely on the corporation's registration to do business and appointment of an agent under a state statute lacking explicit reference to any jurisdictional implications." Id. at 638-39.

193. Goodyear Dunlop Tires Operations, S.A. v. Brown, 564 U.S. 915, 926 (2011) (emphasis added) (quoting Donahue v. Far E. Air Transp. Corp., 652 F.2d 1032, 1037 (D.C. Cir. 1981)).

194. In re Syngenta AG MIR 162 Corn Litig., No. 14-md-2591-JWL, 2016 WL 1047996, at *2 (D. Kan. Mar. 11, 2016) (citing Forest Labs., 2015 WL 880599, at*13). 
In short, the Supreme Court settled the issue of consent-byregistration one hundred years ago. Although decided in an era where the Court rationalized personal jurisdiction on notions of "physical presence," Pennsylvania Fire remains a viable means of obtaining jurisdiction over foreign corporations. The Court never explicitly overturned its holding in Pennsylvania Fire and its progeny, and its recent at home test does not preclude its application to courts considering consent-by-registration today. As this section has shown, consent-byregistration continues to satisfy due process because the Court has continuously affirmed the practice and declined to overturn Pennsylvania Fire.

\section{Explicit Consent Promotes the Due Process Principles of the At}

Home Trilogy

Permitting consent-by-registration promotes the policy goals articulated by the Supreme Court in the at home trilogy. The trilogy significantly narrowed the scope of general jurisdiction over foreign corporations and held that they may ordinarily be subject to general jurisdiction in their state of incorporation and principal place of business. ${ }^{195}$ The Court did not, however, limit the exercise of general jurisdiction over foreign corporations to these forums exclusively. ${ }^{196}$ In fact, the reasoning behind the Court's narrowing of general jurisdiction to these forums also supports affirming consent-by-registration.

The trilogy sought to promote simple jurisdictional rules which create predictable forums where corporations will be subject to general jurisdiction. ${ }^{197}$ A more predictable system is preferable because it permits "out-of-state defendants to structure their primary conduct with some minimum assurance as to where that conduct will and will not render them liable to suit." 198 The Court recently affirmed its intent to craft predictable and simple general jurisdiction rules and confirmed that this intent applies to all state court assertions of personal jurisdiction. ${ }^{199}$ Consent-by-registration furthers these policy goals and does not offend

\footnotetext{
195. Daimler AG v. Bauman, 571 U.S. 117, 137 (2014).

196. Id. at 137-38, 139 n.19 (discussing an "exceptional case" where general jurisdiction could exist outside the state of incorporation and principal place of business and identifying Perkins as fitting within the exception).

197. Id. at 137.

198. Id. at 139 (internal quotations omitted) (quoting Burger King Corp. v. Rudzewicz, 471 U.S. 462, 472 (1985)).

199. See BNSF Ry. Co. v. Tyrrell, 137 S. Ct. 1549, 1559 (2017) (affirming the at home test set forth in Goodyear and Daimler).
} 
due process.

Consent-by-registration promotes Daimler's predictability concerns for general jurisdiction. Large corporations are highly sophisticated entities armed with teams of lawyers charged with investigating legal risks faced by the company. ${ }^{200}$ These investigations naturally include decisions on whether to seek access to the markets of different states and the consequences and effects of registering to do business in different states. $^{201}$ Small businesses, too, engage in these investigations as a matter of routine practice when making choices about where to do business. ${ }^{202}$ Consent-by-registration puts these corporations on notice and allows for voluntary choices about where to predictably subject their business to general jurisdiction.

States with explicit language in their registration statutes extracting consent to general jurisdiction as a condition of doing business dispel any confusion and provide direct awareness to the sophisticated corporate defendant of the consequences of registration, making those corporations "more likely to be on notice of the implications of sending an officer to another forum to conduct business." ${ }^{203}$ The corporation is additionally on notice because registration requires filling out and submitting documents which spell out the consequences of registration. ${ }^{204}$ This process allows foreign corporations the opportunity to make voluntary decisions about where they chose to subject themselves to suit. If a corporation calculates that the risk of being subjected to suit on any claim in a state with explicit consent is too high, it may decline to register to do business there. Or, it may accept that risk and register. Whatever the case, the corporation makes the decision and will never be subjected to general jurisdiction in an unpredictable forum.

\section{CONCLUSION}

After the "at home" trilogy, plaintiffs face a new reality. Where before plaintiffs could rely on business contacts to subject a foreign corporation to general jurisdiction, now plaintiffs may only establish general jurisdiction in the state of incorporation and principal place of business. And given the concurrent narrowing of specific jurisdiction, plaintiffs could find it difficult to locate a suitable forum without

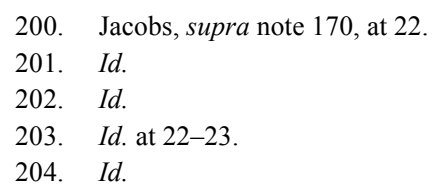


incurring significant expense. Although consent-by-registration potentially presents an alternative means of subjecting large corporate defendants to suit away from home, lower courts have thus far conclusively rejected consent-by-registration. Because the overwhelming majority of the post-trilogy cases involve implicit consent-by-registration, courts have not resolved the issue of explicit consent-by-registration. The case for explicit consent-by-registration is clear because the arguments against implicit consent-by-registration do not apply when a state expressly conditions registration on consent to general jurisdiction. After the at home trilogy, explicit consent-byregistration should provide plaintiffs with new hope of subjecting a corporation to general jurisdiction outside the place of incorporation and principle place of business. 